University of South Florida

DIGITAL COMMONS

Digital Commons @ University of

@ UNIVERSITY OF SOUTH FLORIDA

South Florida

6-1-1996

\title{
High-Resolution $\left(10^{4}\right)$ Years Deep-Sea Foraminiferal Stable Isotope Records of the Eocene-Oligocene Climate Transition
}

James C. Zachos

University of California

Terrence M. Quinn

University of South Florida, quinn@marine.usf.edu

Karen A. Salamy

University of California

Follow this and additional works at: https://digitalcommons.usf.edu/msc_facpub

Part of the Marine Biology Commons

\section{Scholar Commons Citation}

Zachos, James C.; Quinn, Terrence M.; and Salamy, Karen A., "High-Resolution (10 ${ }^{4}$ ) Years Deep-Sea Foraminiferal Stable Isotope Records of the Eocene-Oligocene Climate Transition" (1996). Marine Science Faculty Publications. 161.

https://digitalcommons.usf.edu/msc_facpub/161

This Article is brought to you for free and open access by the College of Marine Science at Digital Commons @ University of South Florida. It has been accepted for inclusion in Marine Science Faculty Publications by an authorized administrator of Digital Commons @ University of South Florida. For more information, please contact digitalcommons@usf.edu. 


\title{
High-resolution $\left(10^{4}\right.$ years $)$ deep-sea foraminiferal stable isotope records of the Eocene-Oligocene climate transition
}

\author{
James C. Zachos \\ Earth Sciences Department, University of California, Santa Cruz \\ Terrence M. Quinn \\ Department of Geology, University of South Florida, Tampa
}

Karen A. Salamy

Marine Science Board, University of California, Santa Cruz

\begin{abstract}
We have constructed high-resolution (104-105 years) benthic foraminiferal $\delta^{13} \mathrm{C}$ and $\delta^{18} \mathrm{O}$ records for the upper Eocene through lower Oligocene of two pelagic sequences, Deep Sea Drilling Project (DSDP) Site 522 in the Angola Basin, South Atlantic Ocean, and Ocean Drilling Program (ODP) Site 744 in the southern Indian Ocean. These records provide improved constraints on both the timing and magnitude of marine oxygen and carbon isotope events from 30 to $35 \mathrm{Ma}$. The oxygen isotope records indicate that the ubiquitous $\delta^{18} \mathrm{O}$ increase (Oi-1), which marks the rapid expansion of continental ice sheets and a minimum of $3^{\circ}$ to $4^{\circ} \mathrm{C}$ of cooling of bottom waters in the earliest Oligocene ( $33.6 \mathrm{Ma}$ ), occurred in $<350 \mathrm{kyr}$. More than half the transition occurred over the final 40-50 kyr. This period of lower temperatures and widespread continental glaciation persisted for roughly $400 \mathrm{kyr}$ (i.e., the duration of magnetochron C13n). These records also indicate that this interval was characterized by at least two $\sim 100-\mathrm{kyr}$ waxing and waning cycles (Oi-1a and Oi-1b) and possibly several higher-frequency events. The benthic foraminiferal $\delta^{13} \mathrm{C}$ records show a positive $0.8 \%$ excursion that is nearly isochronous with the Oi1 oxygen isotope increase. Similar magnitude $\delta^{13} \mathrm{C}$ increases at other sites indicate this was a global phenomenon suggestive of an unusually large perturbation to the carbon cycle. This excursion was followed by smaller amplitude $\delta^{13} \mathrm{C}$ oscillations with periods of roughly $\sim 400 \mathrm{kyr}$. We suspect that the ubiquitous $\mathrm{Oi}-1 \delta^{13} \mathrm{C}$ excursion resulted from a brief but substantial increase in export production and carbon burial.
\end{abstract}

\section{Introduction}

Antarctic ice sheets have a significant influence on the climate and ccology of the oceans on both regional and global scales. They enhance the vigor of atmospheric circulation by acting as an enormous heat sink that steepens the latitudinal thermal gradient of the southern hemisphere [e.g., Flohn, 1984]. Low temperatures and strong, persistent winds generated over the ice sheets help sustain the rapid production of Antarctic Bottom Water (AABW) by accelerating sea-ice formation and cooling of surface waters. These same winds also heighten the fertility of the Southern Oceans by intensifying surface circulation and creating upwelling along frontal zones and by delivering fine iron rich dust from Antarctica [e.g., Martin, 1990]. On geologic timescales, continental ice sheets also influence other critical components of the Earth system

Copyright 1996 by the American Geophysical Union.

Paper number 96PA00571.

0883-8305/96/96PA-00571 $\$ 12.00$ including sea level, land/sea surface coverage, planetary albedo, continental weathering rates, and ocean chemistry, each of which has the potential to trigger large-scale physical and geochemical feedbacks [e.g., Matthews and Poore, 1980; Barron, 1985; Gibbs and Kump, 1994]. Hence efforts to understand the nature of past changes in global climate, particularly in ocean and atmospheric circulation, require a fundamental understanding of Antarctic ice sheet evolution.

In the time since the first marine sediments were cored on and near Antarctica, substantial evidence has accumulated indicating that the most prominent step in the long-term transition from a non glaciated or minimally glaciated planet, or "doubt-house world", to a unipolar, glaciated planet, or "icehouse world", occurred in the earliest Oligocene ( $34 \mathrm{Ma}$ on Cande and Kent's [1992] timescale). Glaciomarine sediments recovered on and near Antarctica strongly suggest that grounded ice sheets were present on much of east Antarctica by the earliest Oligocene [e.g., Barrett, 1989; Barron et al., 1989; Schlich et al., 1989; Hambrey et al., 1991; Breza and Wise, 1992]. This evidence is consistent with the benthic foraminiferal oxygen isotope record which shows a ubiquitous 
$>1.0 \%$ increase coeval with a period of widespread ice rafting [e.g., Shackleton and Kennett, 1975; Kennett and Shackleton, 1976; Keigwin, 1980; Poore and Matthews, 1984; Miller and Thomas, 1985; Keigwin and Corliss, 1986; Miller et al., 1987; Stott et al., 1990; Mackensen and Ehrmann, 1992; Robert and Chamley, 1992; Robert and Kennett, 1992; Zachos et al., 1992a]. This significant climatic transition was unusual in that it appears to have occurred very rapidly, possibly in less than several $100 \mathrm{kyr}$ [Kennett and Shackleton, 1976]. Moreover, detailed paleoclimatic records suggest that the transition to glacial conditions was not a simple step function; it may have begun with a transient climate characterized by much colder conditions and/or larger ice sheets [Shackleton, 1986; Miller et al., 1991; Zachos et al., 1992b, 1993].

The abruptness and scale of the early Oligocene transition and its possible influence on the turnover of some marine and terrestrial biota [e.g., Benson et al., 1984; Hansen, 1992; Hooker, 1992; Wolfe, 1992] make it one of the most influential events of the Cenozoic. However, only a few Eocene/Oligocene successions have been studied with sufficient temporal resolution to document the short-term $\left(10^{4}-10^{5}\right.$ years) paleoenvironmental changes associated with this transition, and these studies have focused primarily on quantifying changes in the physical properties of sediments [Mead et al., 1986; Diester-Haass, 1992, 1995]. For practical reasons, all previous stable isotope investigations used relatively low resolution ( $>10^{5}$ years) sampling that was sufficient for identifying large-scale features of the early Oligocene transition but inadequate for characterizing its finer-scale features. As a result, many fundamental questions regarding the nature of this event remain unanswered.

A primary objective of this investigation was to constrain the timing and magnitude of climatic and environmental changes associated with this transition, specifically the rate at which ice volume and bottom-water temperature changed during the early Oligocene oxygen isotope excursion. To this end, we constructed high-resolution oxygen and carbon isotope and percent sand fraction records spanning the early Oligocene climate transition at two locations, Site 522, a midlatitude site in the South Atlantic, and Site 744, a highlatitude site in the southern Indian Ocean. Benthic foraminiferal isotopic records already exist for both sites [Poore and Matthews, 1984; Vergnaud-Grazzini and Oberhansli, 1986; Miller et al., 1988; Barrera and Huber, 1992; Mackensen and Ehrmann, 1992], but the sample spacing of these records is insufficient $(\sim 100-150 \mathrm{~cm})$ to constrain rapid changes in climate. In preparing our records, we collected samples using a $8-10 \mathrm{~cm}$ sampling interval, providing a temporal resolution of roughly every 8-10 kyr. While these records show essentially the same first- and second-order features as the original low-resolution records, they also reveal many important higher-order features that were not resolved in the original records.

\section{Methods and Materials}

Ten cubic centimeter samples were collected at $9 \mathrm{~cm}$ intervals from Site 522 and at $10 \mathrm{~cm}$ intervals from Site 744 . The 9 $\mathrm{cm}$ sampling interval at Site 522 yields a temporal resolution of $8-9 \mathrm{kyr} / \mathrm{sample}$, while the $10 \mathrm{~cm}$ sampling interval at 744 provides a 10-12 kyr/sample resolution. Samples were freeze dried, weighed, disaggregated in a sodium hexametaphosphate solution, wet sieved through $63 \mu \mathrm{m}$ sieves, rinsed with deionized water and methyl alcohol, and then dried at room temperature. The residual $>63 \mu \mathrm{m}$ fraction was weighed to obtain percent sand fraction ( $\mathrm{g}>63 \mu \mathrm{m} / \mathrm{g}$ bulk sediment). Several species of benthic foraminifera, Cibicidoides havanensis, Cibicidoides grimsdalei, Cibicidoides spp., and Gyroidinoides spp., were hand picked from the $>150 \mu \mathrm{m}$ size fraction of each sample. Specimens were cleaned manually since many from Site 522 were filled with a semilithified micritic material that was difficult to remove using ultrasonic techniques. Each specimen was broken with a glass rod and large fragments isolated and gently agitated in deionized water with a picking brush until contaminant debris was removed. The fragments were then loaded into stainless steel boats and roasted under vacuum at $390^{\circ} \mathrm{C}$ for 1 hour. Isotopic measurcments were performed on 1-15 specimens. For many samples, specimens were analyzed individually to identify the true variability within a sample, while for other samples, specimens were analyzed in groups. All Site 522 samples and roughly half of the Site 744 samples were analyzed using a Kiel automated carbonate device coupled to a Finnegan Mat 251 Mass Spectrometer (University of Michigan). In this system, each sample is reacted in a separate vessel with three drops of phosphoric acid at $75^{\circ} \mathrm{C}$. The resulting gas is distilled in a single step. The remaining Site 744 samples were analyzed using an Autocarb device coupled to a Fisons Prism Mass Spectrometer (University of California, Santa Cruz). In this system, each sample is reacted in a common acid bath at $90^{\circ} \mathrm{C}$. All values are reported in the delta (per mil) notation relative to the Pee Dee belemnite (PDB) standard. External analytical precision based on replicate analyses of four standards, NBS-19, LV-2, NBS-18 and 748B, was better than $0.1 \%$ for both $\mathrm{O}$ and $\mathrm{C}$ isotopes in both laboratories. Unless otherwise stated, all isotope values discussed in this paper are relative to the PDB standard.

\section{Site Locations and Lithologies}

Deep Sea Drilling Project (DSDP) Site 522 is located on a broad, featureless plain within the Angola Basin at a water depth of $4444 \mathrm{~m}$ (Figure 1) [Hsu et al., 1984]. The upper Eocene and lower Oligocene section sampled in this study extends from 60 to 150 meters below seafloor (mbsf) with nearly $100 \%$ recovery of the section. The sediments consist primarily of coccolith ooze with minor amounts of foraminifera and clay. Carbonate content exceeds $85 \%$ throughout most of this interval [Hartl et al., 1995]. The recovered sediments show no obvious core disturbance.

ODP Site 744 is located on southern Kerguelen Plateau at $2307 \mathrm{~m}$ water depth (Figure 1). Recovery of the upper Eocene and lower Oligocene section in Hole 744A extending from 120 and 170 mbsf was better than $98 \%$ [Barron et al., 1989]. The sediments consist mainly of coccolith ooze with minor amounts of foraminifera, diatoms, radiolaria, and clay. Siliceous microfossil concentrations increase from less than a few percent in the Eocene to as much as $10 \%$ in lower Oligocene sediments. Carbonate contents range from 60 to $90 \%$ and vary inversely with silica concentration. Traces of 


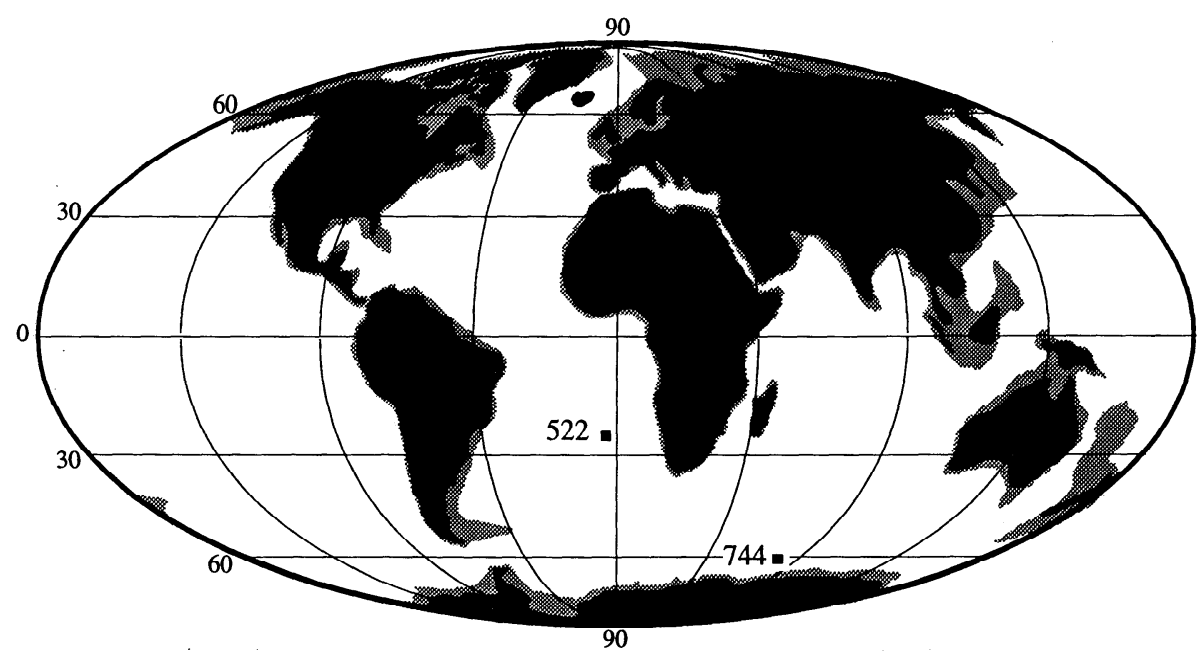

Figure 1. Locations of Deep Sea Drilling Project (DSDP) Site 522 in the Cape Basin and Ocean Drilling Program (ODP) Site 744 on Kerguelen Plateau.

ice-rafted debris consisting of coarse sand grains (quartz and feldspar) are common in lower Oligocene sediments between 140 and 150 mbsf.

In general, preservation of planktonic foraminifera from both sites is moderate to excellent [Poore, 1984; Huber, 1991]. At Site 522, preservation improves slightly from the Eocene to the Oligocene. Benthic foraminifera show little to no evidence of dissolution at either site [Clark and Wright, 1984], although many specimens from Site 522 were infilled with a micritic carbonate.

\section{Chronostratigraphy and Stratigraphic Completeness}

The age models for Sites 522 and 744 are based on the published magnetostratigraphies for each site (Table 1) [Tauxe et al., 1983; Mead et al., 1986; Keating and Sakai, 1991] calibrated to the geomagnetic polarity timescale (GPTS) of Cande and Kent [1992]. Late Eocene to early Oligocene Chrons 12 and 13 and their subchrons are present at both sites, suggesting uninterrupted sedimentation. The Site 522 magnetostratigraphy yields sedimentation rates of $1.2 \mathrm{~cm} / \mathrm{kyr}$ in Chron C13, compared to 0.83 and $0.90 \mathrm{~cm} / \mathrm{kyr}$ in Chrons C15 and $\mathrm{C} 12$, respectively (Table 1 ). Continuity of sedimentation at this site is supported by $\mathrm{Sr}$ isotope stratigraphy which gives no indication of a major unconformity [Miller et al., 1988]. Sedimentation rates at Site 744 averaged $0.8-1.2 \mathrm{~cm} / \mathrm{kyr}$ through the late Eocene and most of the early Oligocene [Barron et al., 1989; Wei, 1992]. The only significant gap at Site 744 is a 2-Myr hiatus separating the upper and lower Oligocene (above Chronozone C11). Some section may also be missing due to core expansion from the intervals between

Table 1. Depth and Ages of Upper Eocene and Lower Oligocene Chron Boundaries and Sedimenation Rates at Sites 522 and 744

\begin{tabular}{|c|c|c|c|c|c|}
\hline Chron & $\begin{array}{l}\text { Age, } \\
\mathrm{Ma}\end{array}$ & $744 \mathrm{mbsf}$ & $\begin{array}{c}\text { 744 S.R., } \\
\text { m/Myr }\end{array}$ & $522 \mathrm{mbsf}$ & $\begin{array}{c}\text { 522 S.R., } \\
\text { m/Myr }\end{array}$ \\
\hline C7An base & 25.63 & 100.20 & & & \\
\hline C8n-1 top & 25.81 & 104.79 & & & \\
\hline C8n-2 base & 26.53 & 111.82 & & & \\
\hline C.9n-1 top & 27.00 & 115.30 & & & \\
\hline Hiatus & 27.09 & 118.20 & & & \\
\hline C11n base & 30.07 & 118.37 & & & \\
\hline \multirow[t]{2}{*}{ C12n top } & 30.45 & 119.36 & & 104.35 & \\
\hline & & & 11.94 & & \\
\hline \multirow[t]{2}{*}{ C12n base } & 30.92 & 124.89 & & & 9.28 \\
\hline & & & 6.73 & & \\
\hline \multirow[t]{2}{*}{ C13n-1 top } & 33.05 & 139.25 & & 128.47 & \\
\hline & & & 14.99 & & 11.72 \\
\hline \multirow[t]{2}{*}{ C13n-2 base } & 33.54 & 146.64 & & 134.25 & \\
\hline & & & 8.00 & & 12.99 \\
\hline \multirow[t]{2}{*}{ C15n-1 top } & 34.67 & 155.65 & & 148.88 & \\
\hline & & & 8.45 & & \\
\hline \multirow[t]{2}{*}{ C15n-2 base } & 34.96 & 158.10 & & & 8.33 \\
\hline & & & 8.56 & & \\
\hline C16n-1 top & 35.37 & 161.60 & & 154.70 & \\
\hline
\end{tabular}

From Tauxe et al. [1983]; Keating and Sakai, [1991]. Chron boundary ages (Ma) are from the geomagnetic polarity time scale (GPTS) of Cande and Kent [1992]. Sedimentation rates (S.R.) for Chrons 12, 13, and 15 are provided as well. 
cores at both sites, a phenomenon that is common in hydraulic piston cores.

\section{Results}

Benthic foraminiferal isotope profiles for Sites 522 and 744 are primarily based on analyses Cibicidoides spp. specimens. To increase the resolution of the isotope stratigraphy, a second record was constructed at Site 522 using Gyroidinoides spp. because Cibicidoides were absent in some samples. In addition to increasing the temporal resolution, this record also provides a means of evaluating the fidelity of the Site 522 oxygen isotope record. Primary paleoenvironmental signals should be seen in both records, whereas "noise" related to vital effects, reworking, and/or analytical precision should not. Other investigations of these taxa have documented a consistent 0.5 to $0.6 \%$ difference in $\delta^{18} \mathrm{O}$ with Gyroidinoides closer to suspected equilibrium [Shackleton et al., 1984; Zachos et al., 1992b]. In this study, analysis of coexisting specimens of Gyroidinoides and Cibicidoides spp. revealed an average $\delta^{18} \mathrm{O}$ difference of $+0.5 \pm 0.15 \%$ o $(2 \sigma, n=183)$ with no discernible trend over time. Carbon isotope values also show a unidirectional but less uniform offset with Cibicidoides $\delta^{13} \mathrm{C}$ values $0.2-0.4 \%$ o higher than those of Gyroidinoides.

\section{Site 522 Stable Isotope Stratigraphies}

The Site $522 \delta^{18} \mathrm{O}$ record (Figure 2) shows several prominent features that are recorded by both Cibicidoides and Gyroidinoides. From 146 to $134.5 \mathrm{mbsf}$, the record shows a gradual 0.6 to $0.7 \%$ increase with several brief excursions toward more positive values. From 134.5 to 133.65 mbsf (just above the $\mathrm{C} 13 \mathrm{n}-\mathrm{r}$ boundary), $\delta^{18 \mathrm{O}}$ values increase by an additional 0.7 to $0.8 \%$. The $\delta 180$ values remain high from 133.2 to 130.0 mbsf (top of the core). Above this interval (base of the overlying core), average values decline by $0.4 \%$. The chronozone $\mathrm{C} 12 / \mathrm{C} 13 \mathrm{r}$ boundary occurs $20 \mathrm{~cm}$ above the coring gap, indicating that the interval of high values is confined to $\mathrm{C} 13 \mathrm{n}$ at this site. The only other significant long-term change is recorded in chron $\mathrm{C} 12 \mathrm{r}$ at $121 \mathrm{mbsf}$, where the mean values decline by another 0.2 to $0.3 \%$.

On a finer scale, the benthic $\delta^{18} \mathrm{O}$ record displays $0.2-0.5 \%$ quasi-periodic cycles. In some intervals, the cycles are more

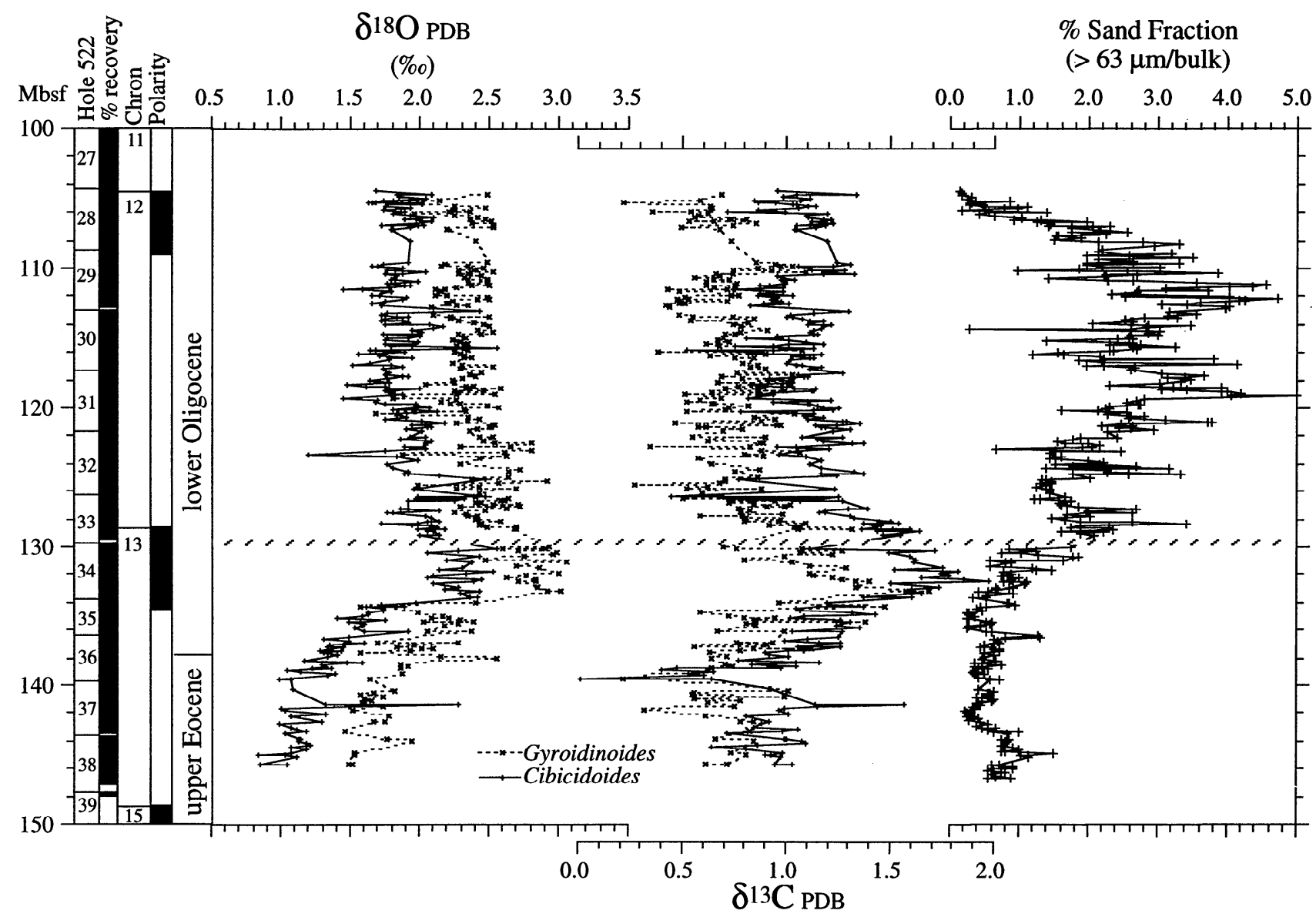

$(\% o)$

Figure 2. Benthic foraminifer stable isotope and percent sand fraction $(<63 \mu \mathrm{m})$ data from Site 522 plotted against meters below sea floor (mbsf). Cibicidoides spp. data are represented by plusses and Gyroidinoides spp. by x's. Core recovery and magnetostratigraphy [Tauxe et al., 1983] are plotted to the left. PDB is Pee Dee belemnite. 
irregular in appearance, but in other discrete intervals the cycles are more regular with Cibicidoides and Gyroidinoides covarying; such covariance indicates that the main signal is not due to analytical noise. One such interval occurs within C13n (130-134 mbsf) where several cycles are present with $\delta^{18} \mathrm{O}_{\mathrm{CIB}}$ and $\delta^{18} \mathrm{O}_{\mathrm{GYR}}$ varying between $2.0-2.6 \%$ and 2.5 $3.1 \%$, respectively (Figure 2). Above this interval and over most of the lower half of $\mathrm{Cl} 2 \mathrm{r}$, the cycles are less regular with an amplitude that is typically $<0.3 \%$. In the upper portion of $\mathrm{C} 12 \mathrm{r}$, despite the continuance of a low-amplitude signal, the cycles again become more regular with $\delta^{18} \mathrm{O}_{\mathrm{CIB}}$ and $\delta{ }^{18} \mathrm{O}_{\mathrm{GYR}}$ exhibiting remarkably tight covariance (e.g., at 105-107 mbsf, $109.5-115 \mathrm{mbsf}$, and 116.5-120 mbsf).

The Site 522 Cibicidoides $\left(\delta^{13} \mathrm{C}_{\mathrm{CIB}}\right)$ and Gyroidinoides $\left(\delta^{13} C_{G Y R}\right)$ carbon isotope records are marked by several distinct long-term trends, the most significant of which is a large shift within chronozone $\mathrm{C} 13$. The increase appears to occur in two steps; from 140 to $135 \mathrm{mbsf}$, values increase by $0.5 \%$ and from 135 to 133 mbsf by another $0.6-0.8 \%$. The $\delta^{13} C_{C I B}$ peaks at a value of $1.85 \% ; \delta^{13} C_{G Y R}$ peaks at a value of $1.52 \%$. From 133 to $125 \mathrm{mbsf}$, values reverse direction decreasing by roughly $0.5-0.7 \%$. Above this level the records exhibit little additional long-term change. On a finer scale, both records exhibit cyclic patterns with wavelengths of $2-5 \mathrm{~m}$ and amplitudes of $0.2-0.5 \%$.

\section{Site 522 Percent Sand Fraction}

The Site 522 percent sand fraction ( $>63 \mu \mathrm{m} / \mathrm{bulk}$ ) record is primarily comprised of planktonic foraminifera. It is marked by a gradual increase upsection that begins at about 134.6 mbsf (Figure 2). Concentrations are relatively uniform below this level, averaging $<1 \%$, with the exception of two small increases centered at 136.4 and 144.9 mbsf. Mean percent sand concentrations gradually rise above $134.6 \mathrm{mbsf}$ doubling to just over $2 \%$ by 128.8 mbsf. Concentrations continue to increase from 128.8 to 112 mbsf with some intervals as high as $4 \%$. Values decrease to less than $2 \%$ from 112 to $104 \mathrm{mbsf}$. In several discrete intervals, including 134.6-130 and $128-118 \mathrm{mbsf}$, the percent sand record shows evidence of higher-frequency oscillations.

\section{Site 744 Stable Isotope Stratigraphies}

The most significant feature of the Site 744 Cibicidoides spp. oxygen isotope record $\left(\delta^{18} \mathrm{O}_{\mathrm{CIB}}\right)$ is a $1.0 \%$ increase in the lowermost Oligocene near the $\mathrm{C} 13 \mathrm{n} / \mathrm{r}$ boundary (Figure 3 ). From 147.81 to $145.90 \mathrm{mbsf}$, values increase from 1.3 to 2.3\%o. Although this transition spans the gap between cores 16 and $18,60 \%$ of the increase occurs within the lowermost 90 $\mathrm{cm}$ of core 16. Oxygen isotope values remain high (2.02.6\%o) to 140 mbsf (just below the $\mathrm{C} 13 / \mathrm{C} 12$ boundary), where they decrease by $0.4 \%$. From 139 to $125.2 \mathrm{mbsf}$, values vary between 1.8 and $2.1 \%$ and show an overall decrease of $\sim 0.3 \%$. Oxygen isotope values reach a minimum of approximately at $125.3 \mathrm{mbsf}$, followed by an abrupt $0.3 \%$ increase at 125.2 mbsf just below the $\mathrm{C} 12 \mathrm{n} / \mathrm{r}$ boundary, another minimum at 120 mbsf, and higher values (2.3 and 2.5\%o) from 118.2 to 114 mbsf.
In general, the amplitude of variability in $\delta^{18} \mathrm{O}_{\mathrm{CIB}}$ is significantly higher above the $\mathrm{C} 13 \mathrm{n} / \mathrm{r}$ boundary than below. Several distinct cycles are apparent, particularly between 120 and 130 mbsf with minima and maxima of between 1.7 and $2.2 \%$.

The Site 744 Cibicidoides spp. carbon isotope record $\left(\delta^{13} C_{C I B}\right)$ can be separated into three intervals. The lowermost interval extends from the base of the sampled section to $148.63 \mathrm{mbsf}$ just below the $\mathrm{C} 13 \mathrm{n} / \mathrm{r}$ boundary. The carbon isotope values in this interval vary between 0.5 and $1.2 \%$, with mean values declining slightly upsection by $0.9 \%$. The next interval, 148.63-138.0 mbsf which falls within C13n, is characterized by higher values with two peaks centered at 146 and 140 mbsf. The transition with the lower interval is marked by a sharp increase from a minimum of $0.53 \%$ at $148.63 \mathrm{mbsf}$ to a maximum of $1.66 \%$ at 145.90 mbst. I ine uppermost interval, 138.0-118 mbsf, lies above $\mathrm{C} 13 \mathrm{n}$ and is characterized by somewhat lower values that vary cyclically between 0.6 and $1.4 \%$ at intervals of $\sim 4 \mathrm{~m}$ or $400 \mathrm{kyr}$.

\section{Orbitally Forced Variations in the Oligocene?}

Previous high-resolution studies of magnetic susceptibility and percent carbonate in the Eocene and Oligocene at Site 522 documented cyclic variations with periods near those associated with Milankovitch orbital forcing of climate change [Mead et al., 1986; Hartl et al., 1995]. Changes in surface productivity and in bottom-water redox conditions in response to climate change are thought to be responsible for the observed periodicity [Hartl et al., 1995]. Hence there is an a priori reason to suspect that Milankovitch forcing may have affected other proxy records of climate change during this period.

To determine whether the high-frequency variations in oxygen isotope and percent sand fraction records may also be orbitally forced, spectral analysis was carried out on discrete intervals of these records. Although the magneto chronological constraints, sedimentation rates, and sampling intervals are not ideal for fully resolving all of the Milankovitch periodicities, the sampling resolution at Site 522 should be sufficient to identify the periodicities associated with eccentricity of the Earth's orbit (100 and $400 \mathrm{kyr}$ ) and the tilt of the Earth's axis (41 kyr). Milankovitch periodicities (19 and $23 \mathrm{kyr}$ ) associated with the precession of the equinoxes cannot be resolved in the records at Sites 522 and 744.

We focused our search for Milankovitch periodicities to the benthic foraminiferal $\delta^{18} \mathrm{O}$ record from Site 522 because it contains the best qualitative evidence of cyclicity and has the higher sedimentation rates. The records of Cibicidoides and Gyroidinoides were combined to form a higher-resolution composite record (Figure 4). The $\delta^{18} \mathrm{O}_{\mathrm{CIB}}$ values were adjusted by $+0.5 \%$ to account for the vital effect difference with Gyroidinoides. In samples with values for both taxa, an isotopic mean and standard deviation were calculated, and this mean value was included in the composite record if the standard deviation was $< \pm 0.2 \%$. We performed spectral analyses using the ARAND software package [Imbrie et al., 1984].

Spectral analysis of the benthic foraminiferal $\delta^{18} \mathrm{O}$ record at Site 522 shows a spectral peak at 41 kyr (Figure 5). This spec- 
tral peak has been widely recognized in Neogene deep-sea isotope records and is associated with changes in the tilt of the Earth's axis [e.g., Imbrie et al., 1984] and is consistent with a strong high-latitude (ice volume) influence on the global climate signal. The quality and precision of the stratigraphic control as well as inability to constrain coring gaps at Site 522 limit the conclusions that can be reached regarding the role of Milankovitch orbital forcing on Paleogene benthic foraminiferal $\delta 180$ records at this time. Nonetheless, we are encouraged to have observed this periodicity in the Site 522 record and hope that when other Eocene/Oligocene deep-sea sites having higher sedimentation rates become available that similar high-resolution studies are performed so as to better determine the role of Milankovitch forcing in the Oligocene.

Although well-defined spectral peaks were not identified in the carbon isotope records in the time series analysis, visually it is clear that quasi-periodic oscillations exist in both records from 31 to $32.5 \mathrm{Ma}$ with periods of $350-450 \mathrm{kyr}$. These cycles, which have amplitudes of roughly $0.2-0.3 \%$, appear to be nearly in phase from 32.5 to $31.7 \mathrm{Ma}$ and $180^{\circ}$ out of phase thereafter. We suspect that the lack of coherence between sites is not real but an artifact of inadequate age control coupled with missing or condensed section (e.g., an undetected hiatus ( 200 kyr) or a condensed interval within the upper part of $\mathrm{C} 12 \mathrm{r}$ at one of the sites). Attempts to improve the correlation using the oxygen isotope record which does not show variability on this scale were largely unsuccessful. Nevertheless, the fact that both sites show similar periods in carbon isotopes during chron $\mathrm{C} 12$ suggests that the carbon cycle was also paced by orbital forcing during the Oligocene. Other records suggest that a similar relationship existed in the Miocene and Eocene epochs as well [Woodruff and Savin, 1991; Zahn and DiesterHaass, 1995].

\section{Late Eocene to Early Oligocene Transition}

The Site 522 and 744 stable isotope records are the highestresolution records available for the latest Eocene-early Oligocene and can be used to evaluate the timing and scale of relatively short-term changes in climate. Here we interpret features that appear in the isotope records of both sites to be global in nature. To facilitate comparison of the isotope stratigraphies, the Cibicidoides isotopic records were each replotted for the period 31-35 Ma using a three-point moving average (Figures 6 and 7).

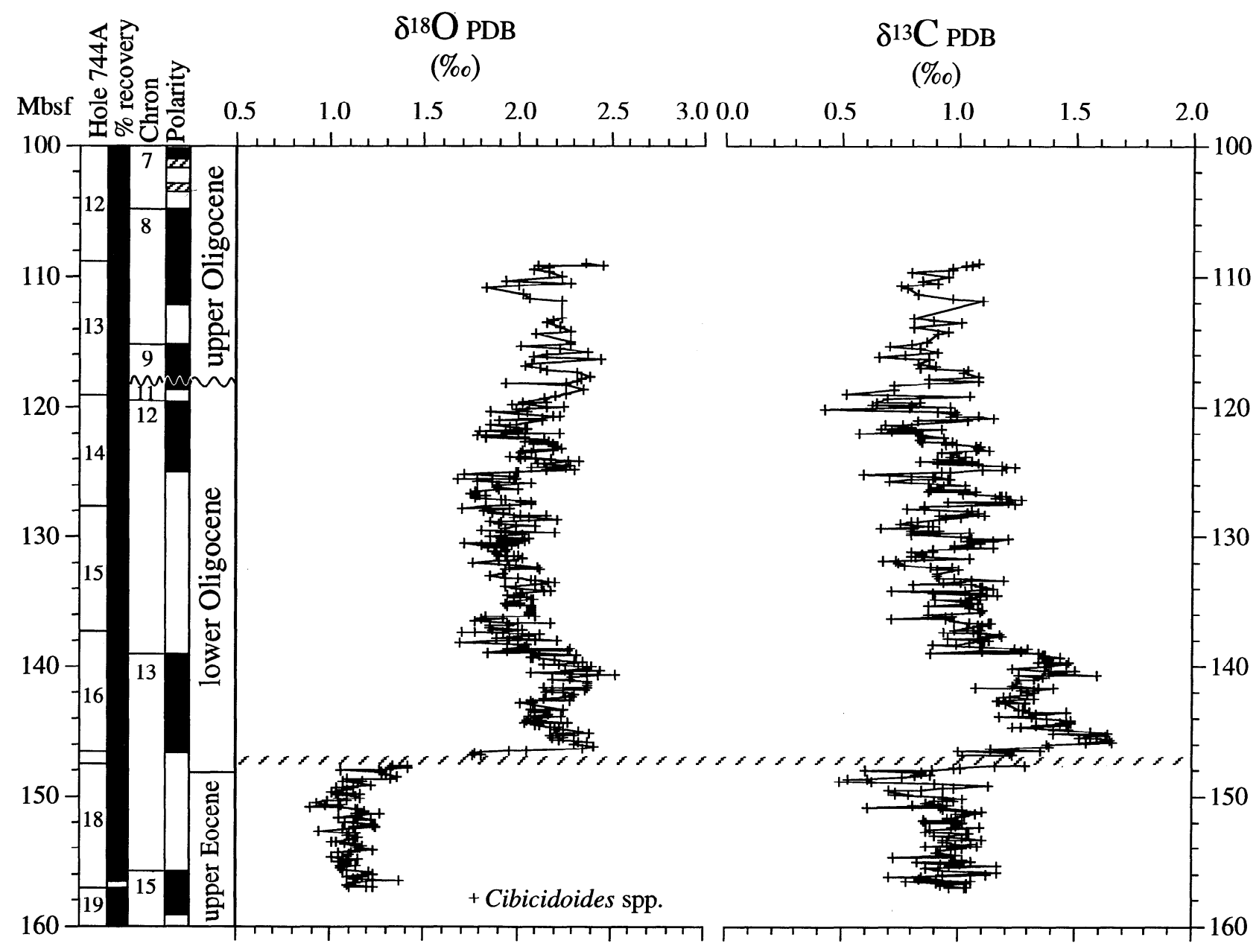

Figure 3. Benthic foraminifer stable isotope data from Site 744 plotted against depth (mbsf). All data are of Cibicidoides spp. Core recovery and magnetostratigraphy [Keating and Sakai, 1991] are plotted to the left. 

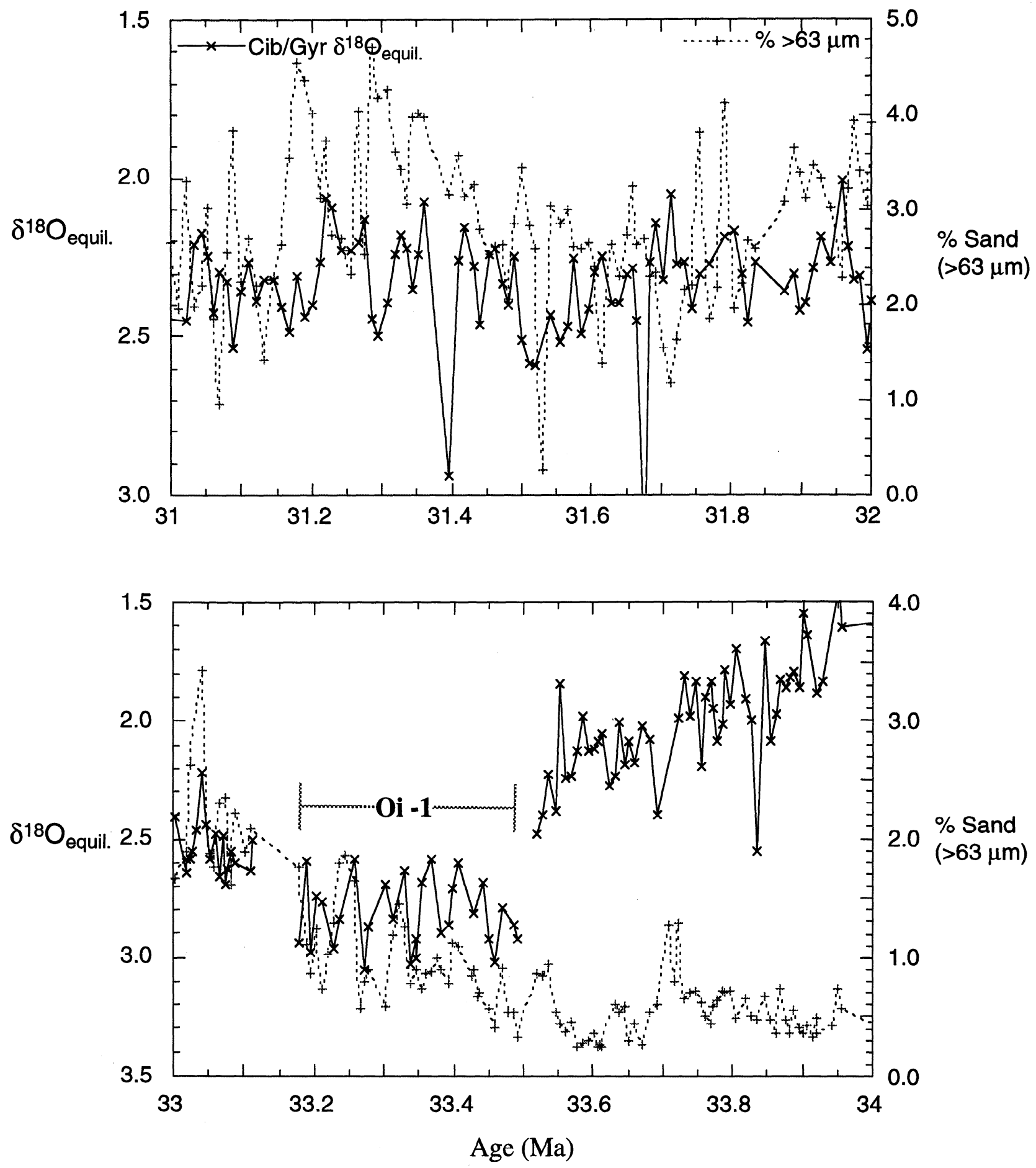

Figure 4. Composite benthic foraminifer equilibrium oxygen isotope data ( $x$ 's) and percent sand fraction data (plusses) from Site 522 plotted against age for two 1 myr intervals relative to the geomagnetic polarity time scale (GPTS) of Cande and Kent [1992]. The oxygen isotope curve is comprised of Cibicidoides spp. data adjusted by $+0.5 \%$ and Gyroidinoides spp. data. The latter is assumed to have an isotopic composition that is close to equilibrium calcite values [Shackleton et al., 1984].

The Timing of Late Eocene and Early Oligocene Oxygen Isotope Events: Global Cooling and Continental Glaciation

The rapid $1.5 \%$ increase in oxygen isotope ratios just above the Eocene/Oligocene boundary has been identified in lower- resolution records from dozens of pelagic sites. The climax of this excursion has been designated Oi-1 by Miller et al. [1991]. The Site 522 and 744 records provide tighter constraints on two important aspects of the Oi-1 event; 1) it's duration; the length of $\mathrm{C} 13 \mathrm{n}$, or for roughly $400 \mathrm{kyr}$, and 2) timing of the initial transition; it was not a single step but 

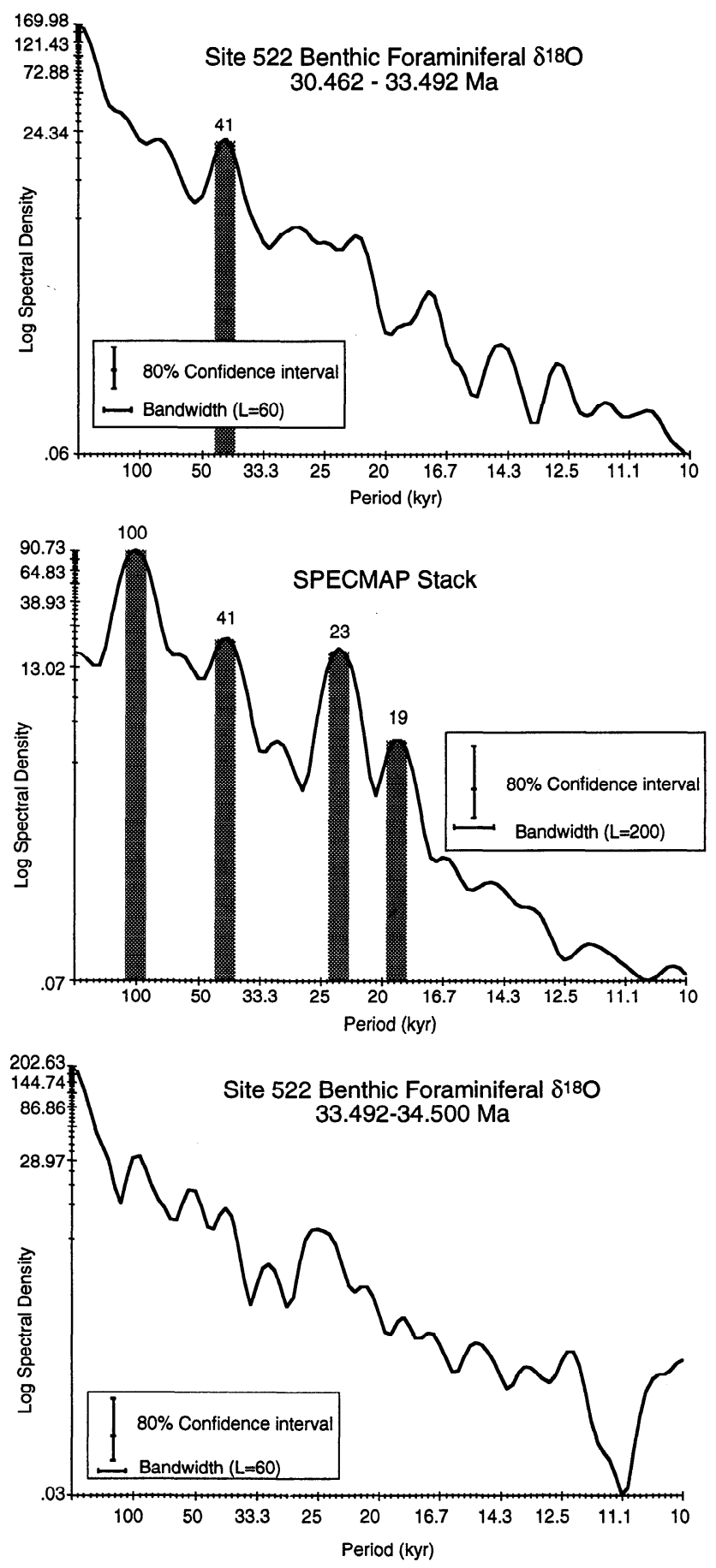

Figure 5. Results of a spectral analysis of the composite benthic foraminifer equilibrium oxygen isotope record from Site 522 for the two periods 31-33.49 and 33.49-34.5 Ma as compared with the expected Milankovitch periods dervied from SPECMAP.

consisted of two phases. The initial phase consisted of a relatively slow rise in values beginning sometime between 33.8 and 34.0 Ma (Figure 6). Values continued to rise by 0.3 to $0.5 \%$ o for the next $300 \mathrm{kyr}$ at which point the rate accelerated. At Site $522, \delta 18 \mathrm{O}$ values increased by an additional $0.8 \%$ in $<50 \mathrm{kyr}$. A similar pattern is observed at Site 744, although the precise timing is not as well constrained because of the coring gap. The close agreement in timing and magnitude of the Oi-1 transition at two sites located in separate basins and at different paleodepths indicates that the relatively rapid nature of the shift is real and not an artifact of local hiatuses or incomplete recovery.

Within Oi-1, the Site 744 profile shows two pronounced peaks of $2.45 \%$ separated by a $150-\mathrm{kyr}$ minima where values are roughly $0.25 \%$ o lower. The two maxima also occur at Site 522 but are not as well defined. In addition, several minima occur between the two maxima at Site 522. The absolute maxima and minima values, however, are nearly identical to those at Site 744 , indicating that these features are reflecting global climate variability. The differences in the approximate timing and duration of these higher-order secondary features between the two sites are probably an artifact of changes in sedimentation rate and/or undetected brief hiatuses within $\mathrm{C13n}$. The climax values may represent the upper limit of the ice volume effect on seawater $\delta^{180}$ for the early Oligocene, possibly an ice sheet size limit set by the accommodation space of east Antarctica. The minimum values may represent the "interglacial" stage ice volumes for that period. Oi-1 thus consisted of two distinct, $\sim 100$ to $150-\mathrm{kyr}$-long glacial maxima which from hereon shall be referred to as Oi-1a and Oi-lb.

The termination of Oi-1 occurred more slowly than its initiation. The post-Oi-1 decline in isotopic values initiated at $33.05 \mathrm{Ma}$ and continued to $32.9 \mathrm{Ma}$ at Site 744 . At Site 522 the Oi-1 termination ended at roughly the same time as at Site 744 , about $32.9 \mathrm{Ma}$; the initiation of the decline is not well constrained as it occurs in a coring gap. Moreover, the postOi-1 decline in values was not monotonic, but rather it was punctuated by several brief positive excursions at both sites.

The similarities in timing and magnitude of the $\mathrm{Oi}-1 \mathrm{a} / \mathrm{b}$ $\delta 180$ excursion at these two sites suggest that these events represent some sort of global change in deep water (i.e., an increase in ice volume and/or a drop in deep-water temperature). Because the benthic foraminiferal oxygen isotope profiles are composites of both parameters (the salinity influence on bottom water $\delta^{18} \mathrm{O}$ can be neglected as a significant variable), it is often difficult to distinguish the relative influences of the two. It is possible, however, with some reasonable assumptions, to place constraints on the amount of ice volume and/or temperature change that would be required to produce a specific response in the oxygen isotope record. In evaluating the oxygen isotope records described above we adopt one such assumption used in earlier studies [e.g., Miller et al., 1987]: bottom-water temperatures at a given location cannot be less than present. Hence, as current bottom water temperatures above Kerguelen Plateau and in the Cape Basin are close to $1^{\circ} \mathrm{C}$, we interpret $\delta^{18} \mathrm{O}$ values in excess of equilibrium values for this temperature as indicating the presence of continental ice sheets.

Equilibrium benthic foraminiferal $\delta 180$ values (attained by adding $0.65 \%$ to Cibicidoides) increase by $1.3 \%$, from roughly $1.7 \%$ o to $3.0 \%$ during the Oi-1 transition (Figure 8 ). Using the seawater/calcite equilibrium $\delta^{18} \mathrm{O}$ equation of Erez and Luz [1983] and assuming a bottom-water temperature of $1{ }^{\circ} \mathrm{C}$, an equilibrium value of $3.0 \%$ yields a seawater isotopic value of $\sim-0.4 \%$ (SMOW). This value (assuming a seawater 


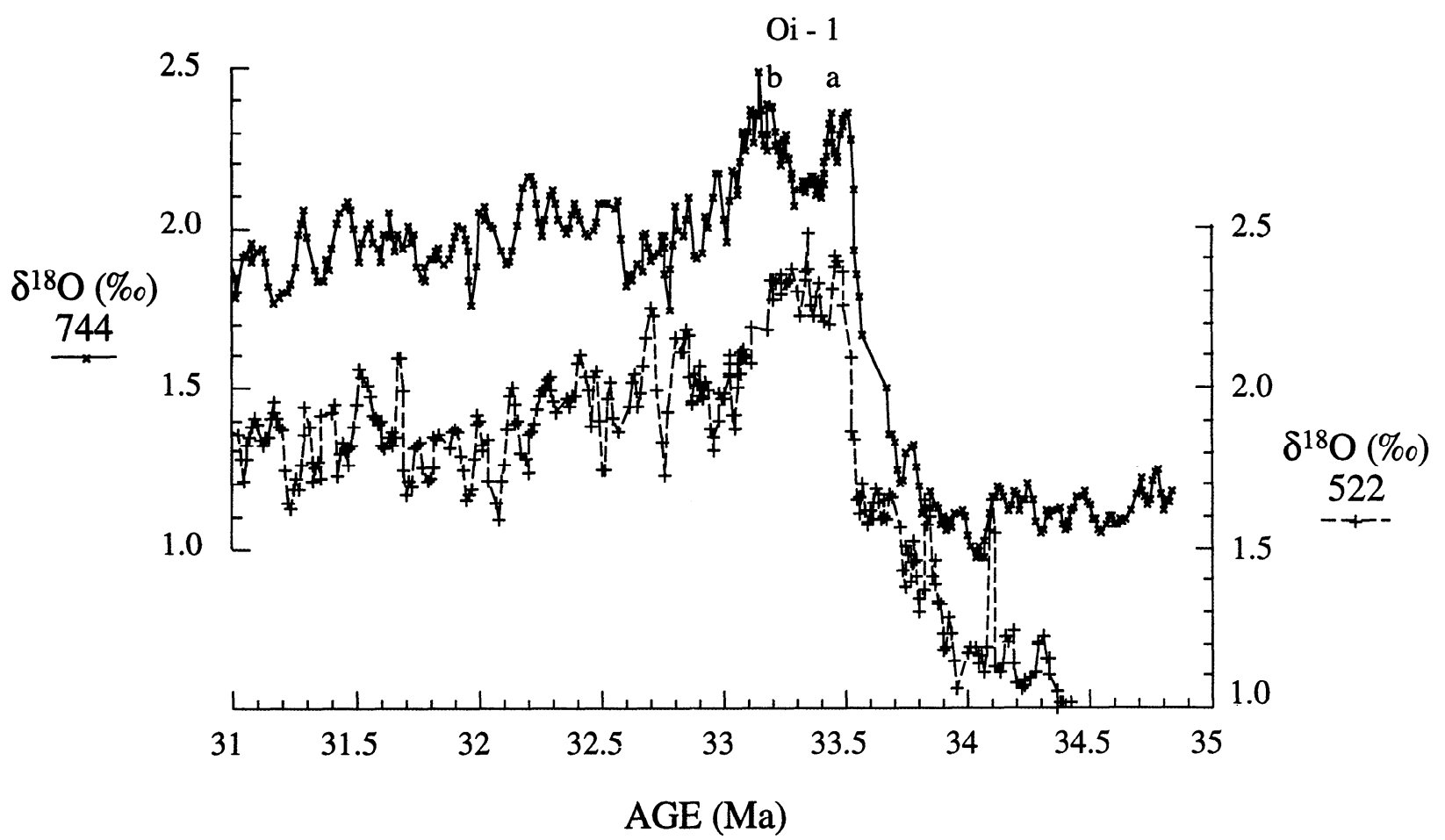

Figure 6. Site 522 (plusses) and 744 (x's) oxygen isotope records plotted as a function of age for the period 31 - $35 \mathrm{Ma}$. The profiles represent a three-point moving average of Cibicidoides data from Site 744 and the composite Cibicidoides and Gyroidinoides data from Site 522. Ages are based on the GPTS of Cande and Kent [1992].

$\delta^{180}$ value of $-1.0 \%$ (SMOW) for an ice-free world) would at a minimum be consistent with a volume of continental ice $40 \%$ of modern ice volume. We emphasize minimum because actual volumes might have been greater if the mean isotopic composition of ice sheets and/or minimum bottom-water temperatures in the Oligocene exceeded those used in our calculations. Thus the remainder of the $\mathrm{Oi}-1$ increase, between 0.8 and $0.9 \%$, must reflect a decline in bottom-water temperatures of approximately $3^{\circ}-4^{\circ} \mathrm{C}$. This decrease, which is slightly smaller than estimated in some previous studies [Savin et al., 1975; Shackleton and Kennett, 1975; Kennett and Shackleton, 1976; Kennett, 1977; Murphy and Kennett, 1986], must also be considered a minimum since it is possible, however remote, that bottom-water temperatures were warmer and that significant ice volume existed prior to the Oi-1 excursion.

In general, with the exception of a few single-point excursions at Site 522, $\delta^{18} \mathrm{O}$ values appear to remain low for the remainder of the early Oligocene but at mean values that are still 0.8 to $1.0 \%$ o higher than just prior to the excursion. The decline in $\delta^{18} \mathrm{O}$ during chron $\mathrm{C} 12 \mathrm{r}$ following the Oi-1 event at both sites reflects a gradual reduction in global ice volume, warming of bottom waters, or some combination of the two. Some degree of warming is supported by the fact that the post Oi-1 decline is slightly larger at Site 522 , resulting in average values that are consistently lower than Site 744 values from 31 to $33 \mathrm{Ma}$. This offset would amount to a $1^{\circ}$ to $2^{\circ} \mathrm{C}$ differential in bottom-water temperature between those two sites. Evidence for an accompanying reduction in ice volume comes from the glacial marine sediment record which indicates that widespread glaciation was limited to just a brief interval of the earliest Oligocene [e.g., Wise et al., 1991] that corresponds to the Oi-1 interval [Zachos et al., 1992a]. This suggests that some portion of the 0.5 to $0.6 \%$ reduction in $\delta^{18 O}$ at the termination of Oi-1 might have been due to partial melting of the ice cap.

\section{Early Oligocene Carbon Isotope Excursion: Implications for Changes in Carbon Burial and Abyssal Circulation}

The Cibicidoides carbon isotope records from Sites 744 and 522 show nearly identical long-term trends over most of the early Oligocene (Figure 8). The most prominent feature common to both records is the large excursion between 33.8 and $33.4 \mathrm{Ma}$, where values rapidly increase by $0.8-1.0 \%$, peaking between 33.4 and $33.5 \mathrm{Ma}$. This carbon excursion appears to lag the Oi-1 oxygen isotope increase by $\sim 20 \mathrm{kyr}$.

It is clear from the Site $\mathbf{5 2 2}$ and 744 isotope profiles that the early Oligocene $\delta^{13} \mathrm{C}$ increase was largely global in scale. This supposition is supported by other, lower-resolution benthic and planktonic records from the Pacific, Atlantic, and Indian Oceans, all of which exhibit similar magnitude $\delta^{13} \mathrm{C}$ increases during the Oi-1 event [Shackleton et al., 1984; Miller and Thomas, 1985; Keigwin and Corliss, 1986; Shackleton, 1986; Rea et al., 1992; Zachos et al., 1992b, 1992c]. Increases related to changes in deep ocean ventilation rates would not be uniform from basin to basin. As a global excursion, the increase in carbon isotope values in the early Oligocene is by most standards a significant event; it is rapid 


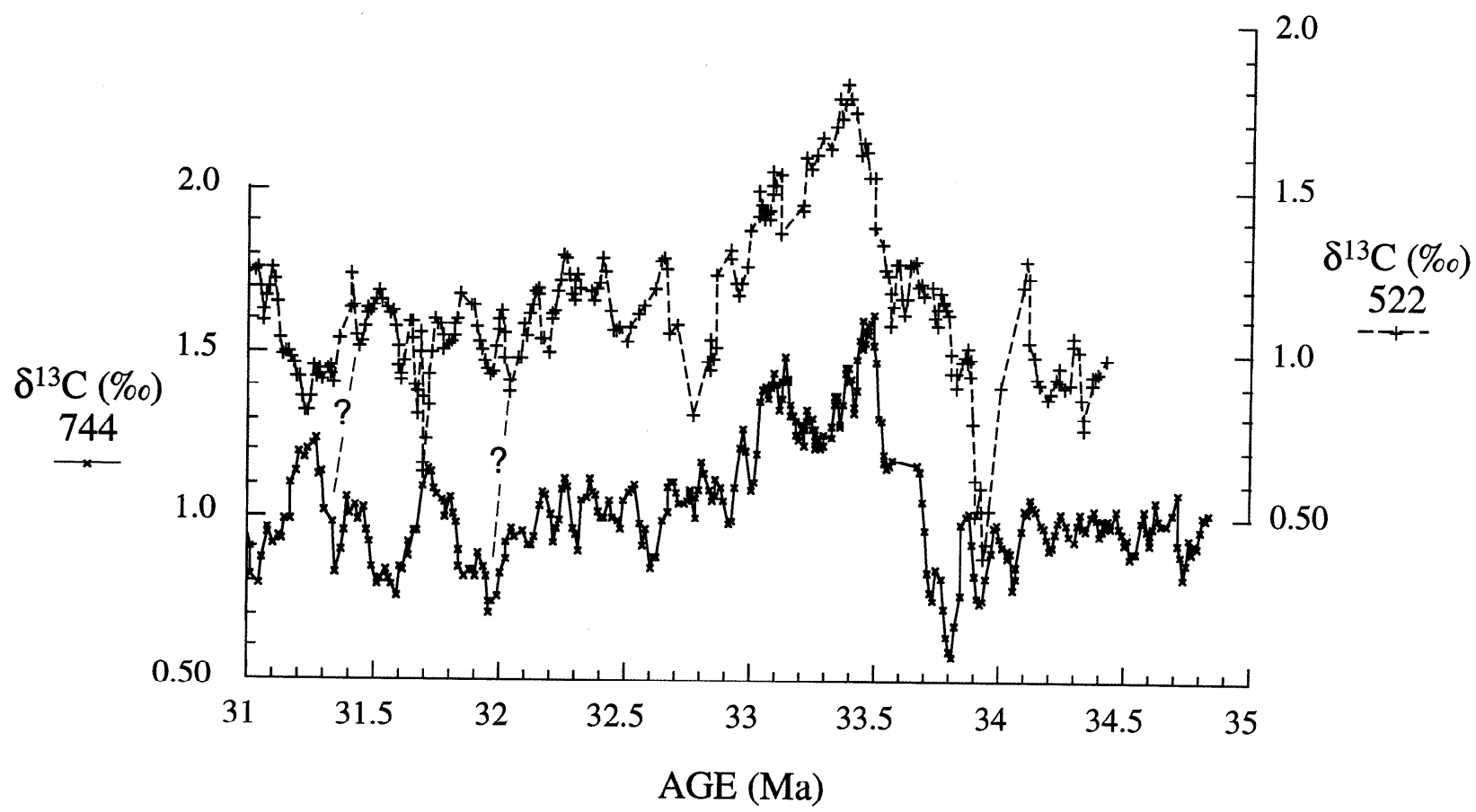

Figure 7. Site 522 (plusses) and 744 (x's) Cibicidoides carbon isotope records plotted as a function of age for the period 31 - $35 \mathrm{Ma}$. Each profile represent a three-point moving average. Ages are based on the GPTS of Cande and Kent [1992].

and large, and the maximum values $(\sim 2.0 \%)$ at the peak of the excursion are as high as any recorded in the ocean during the Eocene and Oligocene [Shackleton, 1986; Zachos et al., 1993]. However, what clearly sets this excursion apart from most others as being significant is the fact that it coincides with Oi-1, suggesting a cause and effect relationship.

Changes in the mean carbon composition of the ocean of this magnitude generally indicate some type of shift in global carbon storage rates. On these timescales, the exchange of carbon with the organic and carbonate carbon reservoirs (i.e., standing and sedimentary) are among the most important fluxes balancing the carbon isotope budget [Berner, 1982; Arthur et al., 1985; Shackleton, 1985]. Because fractionation of carbon to the organic carbon reservoir is large ( - $22.7 \%$ ), a change in the flux of carbon to this reservoir could drive ocean $\delta^{13} \mathrm{C}$ higher. At present, roughly $0.1 \%$ of primary production escapes oxidation and is buried. Isotopically, the removal of this "light" organic carbon $\left(\mathrm{C}_{\text {org }}\right)$ in the ocean is mostly balanced by the burial of carbonate carbon $\left(\mathrm{C}_{\text {carb }} \sim 2.2 \%\right.$ ). It is possible, however, for the production and/or burial of $\mathrm{C}_{\mathrm{org}}$ to increase independently of $\mathrm{C}_{\mathrm{carb}}$. This could be achieved in a number of ways, for example, by increasing the size of the terrestrial. biosphere [Shackleton, 1977] or by partially shifting a percentage of primary production from calcareous to siliceous organisms. Such shifts in $\mathrm{C}_{\text {org }} / \mathrm{C}_{\text {carb }}$ burial ratios can create isotopic imbalances which if sustained for several tens or hundreds of thousands of years are capable of increasing ocean $\delta^{13} \mathrm{C}$ to the extent observed during Oi-1.

Why would $\mathrm{C}_{\text {org }}$ production/burial rates suddenly change during the Oi-1 climate transition? One possibility is that marine fertility had shifted in response to a dramatic change in ocean and atmospheric circulation. As the planetary temperature gradient steepened and an ice sheet appeared on Antarctica during the earliest Oligocene, thermohaline and atmospheric circulation should have intensified leading to higher rates of oceanic turnover [Benson, 1975; Davies et al., 1975; Shackleton and Kennett, 1975; Moore et al., 1978; Boersma et al., 1987; Diester-Haass, 1992, 1995; Diester-Haass et al., 1993; Mackensen and Ehrmann, 1992; Thomas, 1992a, 1992b]. In the Southern Oceans, the strength and persistence of the polar winds would have increased, thereby enhancing the vigor of surface circulation and upwelling [e.g., Barron and Peterson, 1991; Baldauf and Barron, 1990; Baldauf, 1992; Diester-Haass, 1995]. In addition, the supply of limiting nutrients, particularly iron, would have increased substantially as sea level declined and ice sheets and wind began delivering glacial debris to the Southern Oceans [Martin, 1990; de Baar et al., 1995].

Other climate-related changes in the distribution and timing of production would have further enhanced $\mathrm{C}_{\text {org }}$ burial rates. For example, because a greater percentage of detrital organic matter escapes oxidation in regions where $\mathrm{C}_{\text {org }}$ particle flux is greater and sedimentation rates higher [e.g., Emerson and Hedges, 1988], burial rates would have increased during Oi-1 as the balance of production shifted toward upwelling regions. Similarly, with cooling, production should have become more seasonal and/or bloomlike [e.g., de Baar et al., 1995], thus increasing the size of organic aggregates and accelerating the sinking rates of particles from the surface [Berger and Wefer, 1990]. Moreover, a sudden eustatic drop in sea level would have enhanced export production of organic carbon by shifting the highly productive coastal zones toward the outer shelf, 


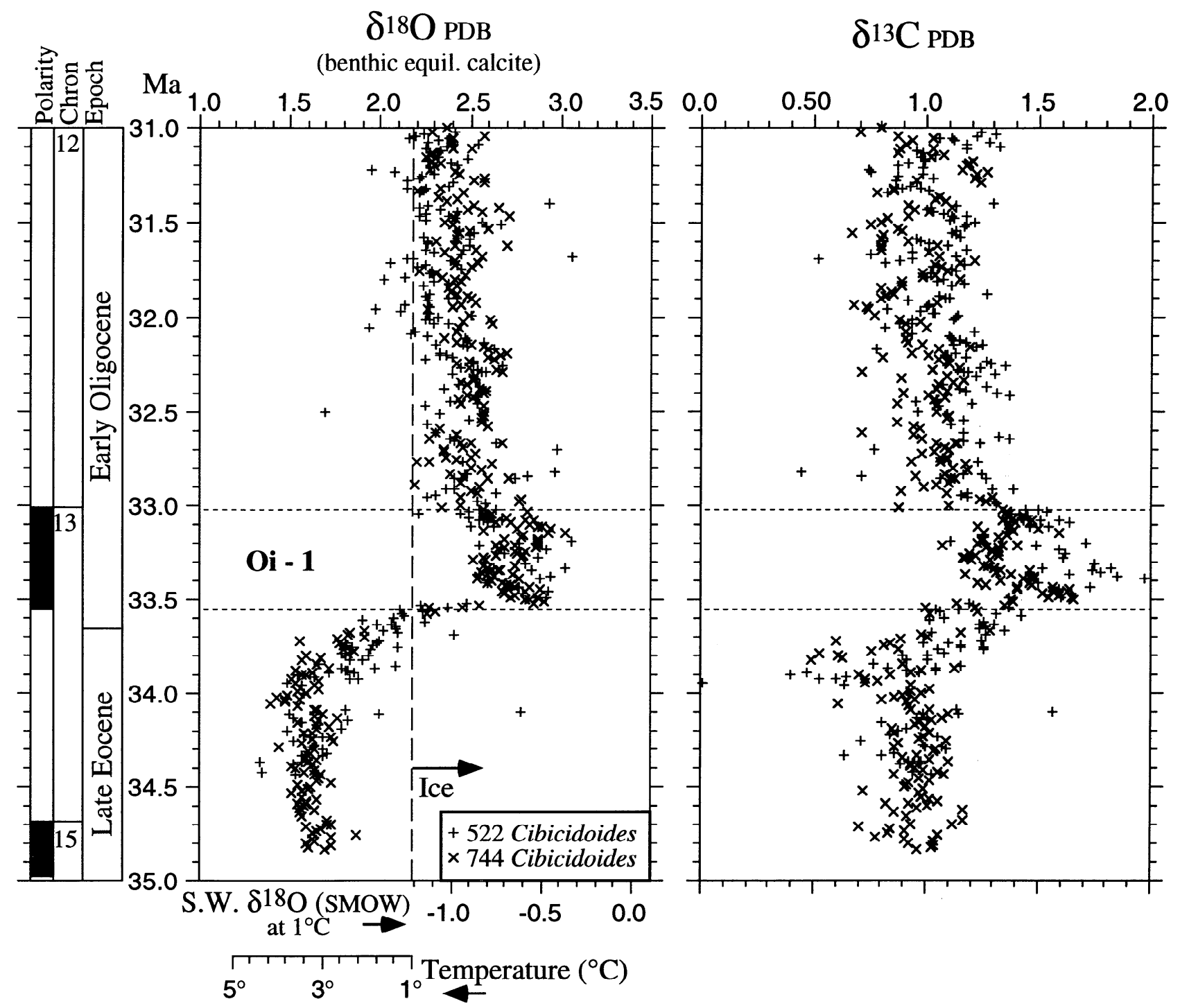

Figure 8. A composite of the Site 522 (plusses) and 744 (x's) Cibicidoides spp. stable carbon and oxygen isotope records plotted as a function of age for the period 31-35 Ma. Ages based on the GPTS of Cande and Kent [1992] plotted to the left. Estimated benthic calcite equilibrium oxygen isotope curve plotted versus age for the $31-35 \mathrm{Ma}$. The curve was derived from the data in Figure 7 adjusted by $+0.5 \%$ o to equilibrium calcite values. All values were computed using the calcite/water/temperature equation of Erez and Luz [1983]. In converting from the SMOW to PDB carbonate scale, $0.27 \%$ was subtracted from seawater $\delta^{18} \mathrm{O}$ values [Hut, 1987; Zahn and Mix, 1991]. The ice-free/ice-volume boundary was computed for a bottom water temperature of $1^{\circ} \mathrm{C}$. Lower axis on right shows estimated minimum $\delta^{18} \mathrm{O}$ composition of seawater (SMOW) at equilibrium with calcite with a fixed bottom water temperature of $1{ }^{\circ} \mathrm{C}$, while axis on left shows estimate of bottom water temperatures for an ice-free Earth with fixed seawater $\delta^{18} 0$ value of $-1.2 \%$ (SMOW).

thereby increasing the opportunity for detrital carbon to be transported to the slope environment where decay processes are slower [Mueller et al., 1983; Sarnthein et al., 1987]. Thus, given these other changes, it is plausible for $\mathrm{C}_{\text {org }}$ burial rates to have increased during Oi-1 even in the absence of overall higher productivity levels.

While this scenario remains untested, considerable evidence exists for a change in marine primary production as described above. At both Sites 744 and 748 on Kerguelen Plateau, opal accumulation rates increased several fold in the earliest Oligocene, particularly during the Oi-1 interval [Barron et al., 1989; Schlich et al., 1989; Baldauf and Barron, 1990; DiesterHaass. 1995; K.A. Salamy et al., manuscript in preparation, 1996]. Evidence for similar increases in equatorial upwelling regions has been documented in the Indian and Atlantic Oceans [Backman et al., 1988; Curry et al., 1995] and along western coasts, implying intensification of wind-driven upwelling. Evidence for changes in terrigenous fluxes in the Southern 
Ocean approximately coincident with the Oi-1 event is evident in clay assemblage and ice-rafted sediment records from the Southern Ocean [Ehrmann and Mackensen, 1992].

\section{North Atlantic Deep Water (NADW) and Abyssal Circulation Change}

One explanation for the separation in carbon isotope values between Sites 522 and 744 during Oi-1 is that the offset is reflecting changes in vertical fractionation of carbon as influenced by local water masses and/or the flux and oxidation of organic carbon from the mixed layer at one or both sites [e.g., Woodruff and Savin, 1991; Wright et al., 1992]. The alternative explanation involves deep-ocean circulation changes. Miller and Fairbanks [1985] suggested on the basis of carbon isotope differences between Pacific and Atlantic benthic foraminifer records that NADW production initiated/intensified synchronously with the Oi-1 oxygen isotope excursion. In this scenario, the carbon composition of Atlantic abyssal waters should be higher than that of the southern Indian Ocean bottom waters at Site 744 during the Oi-1 interval. Since this is exactly the pattern observed in our records, $\delta^{13} \mathrm{C}$ values at Site 522 are several tenths of a per mil higher than the Site 744 values during the Oi-1 interval (33.5-33.1 Ma) (Figure 7); the data would seem to support a temporary circulation change at this time.

\section{Percent Sand Fraction and Preservation}

The Eocene/Oligocene boundary is marked by one of the largest known shifts in the level of the calcite compensation depth (CCD). Lithologic changes in pelagic sediments indicate that the CCD deepened by as much as $1 \mathrm{~km}$ in the equatorial Pacific and by $0.5 \mathrm{~km}$ in the Atlantic and Indian Oceans [Berger, 1973; van Andel, 1975; Thunell and Corliss, 1986; Peterson and Backman, 1990]. Site 522 was at a relatively deep paleodepth ( $3000 \mathrm{~m}$ [Mead et al., 1986]) during the Oligocene and thus would have been particularly sensitive to variations in deep-water carbonate chemistry.

The relative concentration of foraminifera in sediments is influenced by several parameters, including productivity levels (rain ratio) and current intensity (winnowing) and dissolution. The shells of planktonic foraminifera, particularly those of mixed layer taxa, tend to be highly susceptible to dissolution. Since the sand fraction of pelagic sediments is comprised mainly of foraminifera, percent sand or coarse fraction is often used as a qualitative index of dissolution [e.g., Wu et al., 1990; Bassinot et al., 1994].

The percent sand fraction at Site 522 began to systematically increase at roughly $33.5 \mathrm{Ma}$, nearly coincident with the initiation of Oi-1. The response does not appear to be immediate, however; it occurred gradually and in a somewhat oscillatory fashion with each successive peak showing higher concentrations until $33 \mathrm{Ma}$, when values stabilized (Figure 4). This temporal relationship suggests that the shift in carbonate preservation was triggered in some manner by the change in climate.

There are several possible connections. Locally, the lysocline/CCD may have deepened as thermohaline circulation became more vigorous and bottom waters became less corro- sive [Berger, 1973; van Andel, 1975] or as productivity and carbonate accumulation rates increased [Thunnell and Corliss, 1986]. Globally, ocean carbonate chemistry may have been adjusting to an increase in continental weathering fluxes due to glacial erosion and the corresponding drop in sea level (exposing shelf sediments) [Gibbs and Kump, 1994] or to accommodate an alkalinity imbalance created by an increase in $\mathrm{C}_{\text {org }} / \mathrm{C}_{\text {carb }}$ rain ratios. Because the response to changes in burial ratios, productivity, and circulation-driven changes in chemistry should be almost immediate, we suspect that the gradual increase in percentage of sand at Site 522 and the global deepening of the CCD were both being driven by changes in continental weathering rates. The higher-frequency variations, on the other hand, were probably caused by a combination of the above factors.

\section{Speculation on the Origin of the Oi-1 Climate Transition}

Two events are thought to have contributed to the longterm Eocene - Oligocene cooling trend. The first is the systematic widening of the oceanic passages separating Antarctica from South America and Australia, an event that allowed the Circumantarctic current to form [e.g., Barker and Burrell, 1977; Kennett, 1977; Berggren and Hollister, 1977; Berggren, 1982]. The second is an inferred long-term reduction in greenhouse gas levels [e.g., Lasaga et al., 1985; Raymo et al., 1988; Arthur et al., 1991; Freeman and Hayes, 1992]. Numerical modeling experiments indicate that both are capable of creating significant changes in climate and ocean circulation [Barron and Peterson, 1991; Rind and Chandler, 1991; Sloan and Barron, 1992; Mikolajewicz et al., 1993; Sloan and Rea, 1995].

The question we address here is not which of these two factors was more important in driving the long-term cooling but how these or other factors could have triggered and sustained the Oi-1 glacial maximum. It is evident from stable isotope records generated by this study that Oi-1 was an extreme but transient climate (on geologic timescales), lasting $<400 \mathrm{kyr}$. Furthermore, Oi-1 was not a random event in time; it occurred at the transition between two quasi-stable climate modes, the relatively "warm", arguably ice-free Eocene and the "cool", glacial Oligocene. Transient climates of this magnitude are relatively rare in Earth history and indicate a short-term departure from "normal" forcing and/or response.

As far as a greenhouse gas control, there are probably several scenarios that could be invoked to produce a transient glaciation, one of which we shall discuss below. In the case of tectonic forcing, however, it seems that some additional mechanism(s) is required. Volcanic eruptions are capable of briefly lowering global temperature but probably occur too infrequently to sustain cooling for $400 \mathrm{kyr}$. Another possible mechanism to consider is orbital forcing. Zahn and DiesterHaass [1995] have found evidence at ODP Site 689 of low frequency $(-400-\mathrm{kyr})$ oscillations in climate and the carbon cycle through the Eocene and Oligocene. They suggested that Oi-1 along with other cool intervals were being paced by orbital forcing. Although our records do not extend far enough back into the Eocene to test this hypothesis, both carbon isotope records exhibit similar low frequency oscillations 
through the early Oligocene. It seems that under the right circumstances orbital forcing could serve as the final push that propelled a slowly drifting climate system from one mode to another. However, even if orbital forcing was the trigger, another mechanism is required to explain the anomalous conditions of Oi-1.

One other factor may have contributed to this climate transition, internal feedbacks. The climatic response to forcing can be highly nonlinear, even if the forcing is gradual. Slow changes may trigger rapid climate responses as certain "thresholds" are exceeded [North, 1984; Crowley and North, 1988; Manabe and Stouffer, 1988]. Such sudden shifts may in turn initiate a variety of physical and chemical feedbacks, particularly within the ocean/atmosphere system, that amplify the rate and magnitude of change [e.g., Flohn, 1979; Berger, 1982; Southam and Peterson, 1985]. The response of such feedbacks may be most intense during transitions or bifurcations that occur between two distinct climatic modes.

The unprecedented cooling, increase in ice volume, and steepening of the planetary thermal gradient at the onset of Oi1 should have spawned a number of physical and chemical feedbacks. For instance, a $4^{\circ} \mathrm{C}$ cooling of late Eocene sea surface temperatures in deep-water source regions alone would have increased $\mathrm{CO}_{2}$ solubility by as much as $10 \%$ (all else being equal), resulting in a net transfer of carbon from the atmosphere to the deep ocean. Much larger feedbacks, however, may have been triggered as ocean and atmosphere circulation intensified for the first time in millions of years. Increased export production and burial of $\mathrm{C}_{\text {org }}$ together with a globally higher $\mathrm{C}_{\mathrm{org}} / \mathrm{CaCO}_{3}$ burial ratio would have accelerated the removal of carbon from the surface and deep ocean, thereby lowering atmospheric $\mathrm{pCO}_{2}$ [e.g., Vincent and Berger, 1985; Zachos et al., 1993; Derry and France-Lanord, 1996]. The change in $\mathrm{C}_{\text {org }} / \mathrm{CaCO}_{3}$ burial ratio would have been augmented by the partial shift in primary production from carbonate to siliceous organisms in polar and equatorial upwelling zones [e.g., Archer and Maier-Reimer, 1994]. Moreover, the lowering of sea level would have exposed continental shelf carbonates thereby accelerating chemical weathering rates and the draw down of $\mathrm{CO}_{2}$ [Gibbs and Kump, 1994].

One limitation of marine fertility/weathering based feedback as outlined above, however, is that it could only be sustained for a short period of time. For example, nutrient levels, $\mathrm{C}_{\text {org }}$ production, and burial rates would eventually decline as organically bound nutrients were sequestered into sedimentary sinks (in high production regions). Also, to maintain an alkalinity balance, the CCD would eventually deepen (a response that is consistent with the observed changes). The potential response times for such negative feedbacks are thought to be relatively fast, of the order of $10^{3}$ to $10^{4}$ years, which limits the impact and duration of feedbacks on $\mathrm{pCO}_{2}$ and climate. Nevertheless, given the scale of this climate transition, apparent instability of the climate system, and evidence for changes in circulation and carbon cycling, it seems plausible that feedbacks involving these processes may have briefly amplified the response to forcing. This specific hypothesis can be tested with geochemical models and by measuring proxies of productivity and $\mathrm{pCO}_{2}$ in marine sediments across the Oi-1 interval.

\section{Summary and Conclusions}

High-resolution isotopic records were constructed for the late Eocene and early Oligocene, Sites 522 (South Atlantic) and 744 (southern Indian Ocean). These records provide the most detailed account of the climatic and oceanographic changes that accompanied the transition from a "minimally" glaciated to glaciated Antarctic in the early Oligocene. Several large-scale, nearly synchronous features were identified and correlated in the oxygen and carbon isotope records of both sites.

1. The early Oligocene Oi-1 glaciation event was a brief, but extreme cold interval that persisted for the duration of $\mathrm{C} 13 \mathrm{n}(\sim 400 \mathrm{kyr})$ and consisted of at least two distinct events. At the height of the Oi-1 glacial maximum, deep-water temperatures were just slightly warmer than present and an ice cap with a volume at least $50 \%$ of that of the present day existed on east Antarctica.

2. Oi-1 began gradually with benthic foraminiferal $\delta^{18} \mathrm{O}$ values increasing by $0.6 \%$ over $300 \mathrm{kyr}$ and finished rapidly with values increasing by an additional $0.8 \%$ in $50 \mathrm{kyr}$. Roughly $0.5 \%$ of this increase can be attributed to increased ice volume, while the remaining portion must reflect a $3^{\circ}-4^{\circ} \mathrm{C}$ decline in deep-water temperatures.

3. Low-amplitude, higher-frequency oscillations in the benthic foraminiferal $\delta^{18} \mathrm{O}$ record are superimposed on the longerterm isotopic variations at both Sites 522 and 744 . The benthic foraminiferal $\delta^{18} \mathrm{O}$ record at Site 522 shows a spectral peak at $41 \mathrm{kyr}$ (associated with changes in the tilt of the Earth's axis) as has been widely recognized in Neogene deepsea isotope records.

4. The Oi-1 event was accompanied by a transient global carbon isotope excursion which lagged the oxygen isotope shift by several thousands of years. This rapid excursion peaked at carbon isotope values that were as high as any recorded in either basin in nearly 15 Myr. This was subsequently followed by several smaller-amplitude cycles in carbon with periods of $\sim 400 \mathrm{kyr}$.

5. Slight separation of the 522 and 744 benthic carbon isotope records during Oi-1 supports the hypothesis that NADW was briefly active during this period.

6. A gradual increase in Site 522 percent sand fraction synchronous with the onset of the Oi-1 suggests that global deepening of the CCD in the early Oligocene was indirectly linked to the onset of cooling and continental glaciation.

Acknowledgments We are especially grateful to Linda Albertzart and Monique Baker for their technical support and K.C. Lohmann for generously providing access to the University of Michigan Stable Isotope Laboratory. We thank Richard Poore and Liselotte DiesterHaass for providing washed samples from Sites 522 and 744. We also thank Tim Herbert, Kenneth Miller, Ellen Thomas, and James Wright for their very thorough and thoughtful reviews. This project benefited from discussions with Bruce Corliss, Liselotte Diester-Haass, and Rainer Zahn. This research was supported by NSF grant OCE-9101861 to Quinn and Zachos.

\section{References}

Archer, D.E., and E. Maier-Reimer, Effect of deep-sea sedimentary calcite preservation on atmospheric $\mathrm{CO}_{2}$ concentration, Nature, 367 , 260-263, 1994. 
Arthur, M.A., W.E. Dean, and S.O. Schlanger, Variations in the global carbon cycle during the Cretaceous related to climate, volcanism, and change in atmospheric $\mathrm{CO} 2$, in Carbon Cycle and Atmospheric CO2: Natural Variations Archean to Present, Geophys. Monogr. Ser., vol. 32, edited by E.T. Sundquist and W.S. Broecker, pp. 504-529, AGU, Washington, D.C., 1985.

Arthur, M.A., K.R. Hinga, M.E.Q. Pilson, E. Whitaker, and D. Allard, Estimates of $\mathrm{pCO}_{2}$ for the last $120 \mathrm{Ma}$ based on the $\delta^{13} \mathrm{C}$ of marine phytoplanktic organic matter (abstract), Eos Trans. AGU, 72, (17) Spring Meet. Suppl., 166, 1991.

Backman, J., et al., Proceedings of the Ocean Drilling Program, Part A: Initial Reports, vol. 115, Ocean Drill. Program, College Station, Tex., 1988.

Baldauf, J.G., Middle Eocene through early Miocene diatom floral turnover, in Eocene - Oligocene Climatic and Biotic Evolution, edited by D.A. Prothero and W.A. Berggren, pp. 310-326, Princeton Univ. Press, Princeton, N.J., 1992.

Baldauf, J.G., and J.A. Barron, Evolution of biosiliceous sedimentation patterns-Eocene through Quarternary: Paleoceanographic response to polar cooling, in Geological History of the Polar Oceans, Arctic Versus Antarctic, edited by U. Bleil and J. Thiede, pp. 575-607, Kluwer Acad., Norwell, Mass., 1990.

Barker, P.F., and J. Burrell, The opening of the Drake Passage, Mar. Geol., 25, 15-34, 1977.

Barrera, E., and B.T. Huber, Paleogene and early Neogene oceanography of the southern Indian Ocean, Leg 119 foraminifer stable isotope results, Proc. Ocean Drill. Program Sci. Results, 119, 693718, 1991.

Barrett, P.J. (Ed.), Antarctic Cenozoic History From CIROS-1 Drill Hole McMurdo Sound, DSIR Bull. N. Z., 245, 251 pp., 1989.

Barron, E.J., Explanations for the Tertiary global cooling trend, Palaeogeogr. Palaeoclimatol. Palaeoecol., 50, 729-739, 1985.

Barron, E.J., and W.H. Peterson, The Cenozoic ocean circulation based on ocean general circulation model results, Palaeogeogr. Palaeoclimatol. Palaeoecol., 83, 1-28, 1991.

Barron, J.A., et al., Proceedings of the Ocean Drilling Program, Initial Reports, vol. 119, Ocean Drill. Program, College Station, Tex., 1989.

Bassinot, F. C., L. Beaufort, E. Vincent, L. D. Labeyrie, F. Rostek, P. J. Muller, X. Quidelleur, and Y. Lancelot, Coarse fraction fluctuations in pelagic carbonate sediments from the tropical Indian Ocean: A 1500-kyr record of carbonate dissolution, Paleoceanography, 9, 579-600, 1994.

Benson, R.H., The origin of the psychrosphere as recorded in changes of deep-sea ostacode assemblages, Lethaia, 8, 69-83, 1975.

Benson, R.H., R.E. Chapman, and L.T. Deck, Paleoceanographic events and deep-sea ostracodes, Science, 224, 1334-1336, 1984.

Berger, W.H., Deep-Sea carbonates: Evidence for a coccolith lysocline, Deep Sea Res., 20, 917-,921, 1973.

Berger, W.H., Climate steps in ocean history-Lessons from the Pleistocene, in Climate in Earth History, pp. 43-54, Nat. Acad. Press, Washington, D.C., 1982.

Berger, W.H., and G. Wefer, Export production: seasonality and intermittency, and paleoceanographic implications, Palaeogeogr. Palaeoclimatol. Palaeoecol., 89, 245-254, 1990.

Berggren, W.A., Role of ocean gateways in climatic change, in Climate in Earth History, pp. 118-125, Nat. Acad. Press, Washington, D.C., 1982.

Berggren, W.A., and C.D. Hollister, Plate tectonics and paleocirculation - Commotion in the ocean, Tectonophysics, 11, 11-48, 1977.

Berner, R.A., Burial of organic carbon and pyrite sulfur in the modern ocean; its geochemical and environmental significance, Am. J. Sci., 282, 451-473, 1982.

Boersma, A., I. Premoli-Silva, and N. J. Shackleton, Atlantic Eocene planktonic foraminiferal paleo-hydrographic indicators and stable isotope paleoceanography, Paleoceano-graphy, 2, 287-331, 1987.

Breza, J., and S.W. Wise, Lower Oligocene ice-rafted debris on the Kerguelen Plateau, Evidence for East Antarctic continental glaciation, Proc. Ocean Drill. Program Sci. Results, 120, 161-178, 1992.

Cande, S.C., and D. Kent, A new geomagnetic polarity time scale for the Late Cretaceous and Cenozoic, J. Geophys. Res., 97, 13,91713,951, 1992.

Clark, M.W., and R.C. Wright, Paleogene abyssal foraminifers from the Cape and Angola Basins, south Atlantic Ocean, edited by K.J. Hsu et al., Initial Rep. Deep Sea Drill. Proj., 73, 459-480, 1984.
Crowley, T.J., and G.R. North, Abrupt climate change and extinction events in Earth history, Science, 240, 996-1002, 1988.

Curry, W.B., et al., Proceedings of the Ocean Drilling Program, Initial Reports, vol. 154, Occan Drill. Program, College Station, Tex., 1995.

Davies, T.A., O.E. Weser, B.P. Luyendyk, and R.B. Kidd, Unconformities in the sediments of the Indian Ocean, Nature, 253, 15-19, 1975.

de Baar, H.J.W., J.T.M. de Jong, D.C.E. Baker, B.M. Loscher, C. Veth, U. Bathmann, and V. Smectacek, Importance of iron for plankton blooms and carbon dioxide draw down in the Southern Ocean, Nature, 373, 412-415, 1995.

Derry, L.A., and C. France-Lanord, Neogene growth of the sedimentary organic carbon reservoir, Paleoceanography, in press, 1996.

Diester-Haass, L., Late Eocene-Oligocene sedimentation in the Antarctic Ocean, Atlantic sector (Maud Rise, ODP Leg 113, Site 689): Development of surfacc and bottom water circulation, in The Antarctic Paleoenvironment: A Perspective on Global Change, Antarctic Res. Ser., vol. 56, edited by J.P. Kennett and D.A. Warnke, pp. 185-202, AGU, Washington, D.C., 1992.

Diester-Haass, L., Middle Eocene to early Oligocene paleoceanography of the Antartic Ocean (Maud Rise, ODP Leg 113, Site 689): Change from a low to high productivity ocean, Palaeogeogr. Palaeoclimatol. Palaeoecol., 113, 311-334, 1995.

Diester-Haass, L., C. Robert, and H. Chamley, Paleoceanographic and paleoclimatic evolution in the Weddell Sea (Antarctica) during the middle Eocene-late Oligocene, from coarse sediment fraction and clay mineral data (ODP Site 689), Mari. Geol., 114, 233-250, 1993.

Ehrmann, W.U., and A. Mackensen, Sedimentological evidence for the formation of an east Antarctic ice sheet in Eocene/Oligocene time, Palaeogeogr. Palaeoclimatol. Palaeoecol., 93, 85-112, 1992.

Emerson, S., and J.I. Hedges, Processes controlling the organic carbon content of open ocean sediments, Paleoceanography, 3, 621-634, 1988.

Erez, J., and B. Luz, Experimental paleotemperature equation for planktonic foraminifera, Geochim. Cosmochim. Acta, 47, 1025-1031, 1983.

Flohn, H., On time scales and causes of abrupt paleoclimatic events, Quat. Res., 12, 135-149, 1979.

Flohn, H., Climate evolution in the Southern hemisphere and the equatorial region during the late Cenozoic, in Late Cainozoic Paleoclimates of the Southern Hemisphere, edited by J.C. Vogel, pp. 5-20, A.A. Balkema, Rotterdam, Netherlands, 1984.

Freeman, K.H., and J.M. Hayes, Fractionation of carbon isotopes by phytoplankton and estimates of ancient $\mathrm{CO}_{2}$ levels, Global Biogeochem. Cycles, 6, 185-198, 1992.

Gibbs, M. T., and L. R. Kump, Global chemical erosion during the last glacial maximum and the present: Sensitivity to changes in lithology and hydrology, Paleoceanography, 9, 529-543, 1994.

Hambrey, M.J., W.U. Ehrmann, and B. Larsen, Cenozoic glacial record of the Prydz Bay Continental Shelf, East Antarctica, Proc. Ocean Drill. Program Sci. Results, 119, 77-132, 1991.

Hansen, T., The patterns and causes of Molluscan extinctions across the Eocene/Oligocene boundary, in Eocene-Oligocene Climatic and Biotic Evolution, edited by D. A. Prothero and W. A. Berggren, pp. 341-348, Princeton Univ. Press, Princeton, N. J., 1992.

Hartl, P., L. Tauxe, and T. Herbert, Earliest Oligocene increase in South Atlantic productivity as interpreted from "rock magnetics" at Deep Sea Drilling Project Site 522, Paleoceanography, 10, 311-326, 1995.

Hooker, J.J., British mammalian paleocommunities across the EoceneOligocene Transition and their environmental implications, in Eocene-Oligocene Climatic and Biotic Evolution, edited by D. A. Prothero and W. A. Berggren, pp. 494-515, Princeton Univ. Press, Princeton, N. J., 1992.

Hsu, K.J., et al., Initial Reports of the Deep Sea Drilling Project, vol. 73, U.S. Govt. Print. Off., Washington, D.C., 1984.

Huber, B., Paleogene and early Neogene planktonic foraminifera biostratigraphy of Sites 738 and 744, Kerguelen Plateau (southern Indian Ocean), Proc. Ocean Drill. Program Sci. Results, 119, 427450, 1991.

Hut, G., Stable isotope reference samples for geochemical and hydrological investigations, Consultants Group Metting IAEA, Report to the Director General, 42 pp., Int. At. Energy Agency, Vienna, 1987.

Imbrie, J., J. Hays, D. Martinson, A. McIntyre, A. Mix, J. Morley, N. 
Pisias, W. Prell, and N.J. Shackleton, The orbital theory of Pleistocene climate: Support from a revised chronology of the marine $\delta^{18} \mathrm{O}$ record, in Milankovitch and Climate, Part I, edited by A. Berger et al., pp. 269-305, D. Reidel, Norwell, Mass., 1984.

Keating, B.H., and H. Sakai, Magnetostratigraphic studies of sediments from Site 744, southern Kerguelen Plateau, Proc. Ocean Drill. Program Sci. Results, 119, 771-794, 1991.

Keigwin, L.D., Palaeoceanographic change in the Pacific at the Eocene-Oligocene boundary, Nature, 287, 722-725, 1980.

Keigwin, L.D., and B.H. Corliss, Staole isotopes in tate middle Eocene to Oligocene foraminifera, Geol. Soc. Am. Bull., 97, 335-345, 1986.

Kennett, J.P., Cenozoic evolution of Antarctic glaciation, the circumAntarctic Ocean, and their impact on global paleoceanography, $J$. Geophys. Res., 82, 3843-3860, 1977.

Kennett, J.P., and N.J. Shackleton, Oxygen isotopic evidence for the development of the psychrosphere $38 \mathrm{~m}$.y. ago, Nature, 260, 513$515,1976$.

Lasaga, A.C., R.A. Berner, and R.M. Garrels, An improved geochemical model of atmospheric $\mathrm{CO}_{2}$ fluctuations over the past 100 million years, in Natural Variations in Carbon Dioxide and the Carbon Cycle, Geophys. Monogr. Ser., vol. 32, edited by E.T. Sundquist and W.S. Broecker, pp. 397-411, AGU, Washington, D.C. 1985.

Mackensen, A., and W.U. Ehrmann, Middle Eocene through early Oligocene climate history and paleoceanography in the Southern Ocean: Stable oxygen and carbon isotopes from ODP sites on Maud Rise and Kerguelen Plateau, Mar. Geol., 108, 1-27, 1992.

Manabe, S., and R.J. Stouffer, Two stable equilibria of a coupled ocean-atmosphere model, J. Clim., 1, 841-866, 1988.

Martin, J.H., Glacial-Interglacial $\mathrm{CO}_{2}$ change: The iron hypothesis, Paleoceanography, 5, 1-13, 1990.

Matthews, R.K., and R.Z. Poore, Tertiary $\delta^{18} \mathrm{O}$ record and glacioeustatic sea-level fluctuations, Geology, 8, 501-504, 1980.

Mead, G.A., L. Tauxe, and J.J. LaBreque, Oligocene paleoceanography of the South Atlantic: Paleoclimatic implications of sediment accumulation rates and magnetic susceptivility measurements, Paleoceanography, 1, 273-284, 1986.

Mikolajewicz, U., E. Maier-Reimer, T.J. Crowley, and K.Y. Kim, Effect of Drake and Panamania gateways on the cirulation of an ocean model, Paleoceanography, 8, 409-426, 1993.

Miller, K.G., and R.G. Fairbanks, Oligocene to Miocene carbon isotope cycles and abyssal circulation changes, in Carbon Dioxide and Atmospheric $\mathrm{CO}_{2}$ : Natural Variations Archean to Present, Geophys. Monogr. Ser., vol. 32, edited by E.T. Sundquist and W.S. Broecker, pp. 469-486, GU, Washington, D.C., 1985.

Miller, K.G., and E. Thomas, Late Eocene to Oligocene benthic foraminifera isotopic record, site 574, equatorial Pacific, Initial Rep. Deep Sea Drill. Proj., 85, 771-777, 1985.

Miller, K.G., R.G. Fairbanks, and G.S. Mountain, Tertiary oxygen isotope synthesis, sea-level history and continental margin erosion, Paleoceanography, 2, 1-19, 1987.

Miller, K.G., M.D. Feigenson, D. Kent, and R.K. Olsson, Upper Eocene to Oligocene isotope $\left.\left({ }^{87} \mathrm{Sr} 1^{86} \mathrm{Sr}\right), \delta^{18} \mathrm{O}, \delta^{13} \mathrm{C}\right)$ standard section, Deep-Sea Drilling Project Site 522, Paleoceanography, 3, 223-233, 1988.

Miller, K.G., J.D. Wright, and R.G. Fairbanks, Unlocking the ice house: Oliogocene-Miocene oxygen isotopes, eustacy, and margin erosion, J. Geophys. Res., 96, 6829-6848, 1991.

Mook, W.G., J.C. Bommerson, and W.H. Stavermen, Carbon isotope fractionation between dissolved bicarbonate and gaseous carbon dioxide, Earth Planet. Sci. Lett., 22, 169-176, 1974.

Moore, T.C., T.H. Van Andel, C. Sancetta, and N.G. Pisias, Cenozoic hiatuses in pelagic sediments, Micropaleontology, 24, 113-138, 1978.

Mueller, P.J., H. Erlenkeuser, and R. von Grafenstein, Glacialinterglacial cycles in oceanic productivity inferred from organic carbon contents in eastern North Atlantic sediment cores, in Coastal Upwelling, Part B, edited by J. Thiede and E. Suess, pp. 365-398, Plenum, New York, 1983.

Murphy, M. G., and J. P. Kennett, Development of latitudinal thermal gradients during the Oligocene, oxygen isotope evidence from the southwest Pacific, Initial Rep. Deep Sea Drill. Proj., 90, 1347-1360, 1986.

North, G.R., The small ice cap instability in diffusive climate models, $J$. Atmos. Sci., 41, 3390-3395, 1984.
Peterson, L.C., and J. Backman, Late Cenozoic carbonate accumulation and the history of the carbonate compensation depth in the western equatorial Indian Ocean, Proc. Ocean Drill. Program Sci. Results, 115, 467-507, 1990.

Poore, R.Z., Middle Eocene through Quaternary planktonic foraminifers from the southern Angola Basin; Deep Sea Drilling Project Leg, edited by K.J. Hsu et al., Initial Rep. Deep Sea Drill. Proj., 73, 429-448, 1984.

Poore, R.Z., and R.K. Matthews, Oxygen isotope rankings of late Eocene and Oligocene planktonic foraminifers, Implications for Oligocene sea-surface temperatures and global ice-volume, Mar. Micropaleontol., 9, 111-134, 1984.

Raymo, M.E., W.F. Ruddiman, and P.N. Froelich, Influence of late Cenozoic mountain building on ocean geochemical cycles, Geology, 16, 649-653, 1988.

Rea, D.K., K.C. Lohmann, N.D. MacLeod, M.A. House, S.A. Hovan, and G.D. Martin, Oxygen and carbon isotopic records the oozes of ODP sites 752, 754, 756/757, eastern Indian Ocean, Proc. Ocean Drill. Program Sci. Results, 121, 229-240, 1991.

Rind, D., and M. Chandler, Increased ocean heat transports and warmer climate, J. Geophys. Res., 96, 7437-7461, 1991.

Robert, C., and H. Chamley, Late Eocene-Early Oligocene evolution of climate and marine circulation: Deep-Sea clay mineral evidence, in The Antarctic Paleoenvironment: A Perspective on Global Change, Antarct. Res. Ser., vol. 56, edited by J.P. Kennett and D.A. Warnke, pp. 97-118, AGU, Washington, D.C., 1992.

Robert, C., and J.P. Kennett, Paleocene and Eocene kaolinite distribution in the South Atlantic and southern ocean: Antarctic climatic and paleoceanographic implications, Mar. Geol., 3, 99-110, 1992.

Sarnthein, M., K. Winn, and R. Zahn, Paleoproductivity of oceanic upwelling and the effect on atmospheric $\mathrm{CO}_{2}$ and climatic change during deglaciation times, in Abrupt Climatic Change - Evidence and Implication, edited by W.H. Berger and L. D. Laberyrie, pp. 311337, D. Reidel, Norwell, Mass., 1987.

Savin, S.M., R.G. Douglas, and F.G. Stehli, Tertiary marine paleotemperatures, Geol. Soc. Am. Bull., 86, 1499-1510, 1975.

Schlich, R., et al., Proceedings of the Ocean Drilling Program, Initial Reports, vol. 120, Ocean Drill. Program, College Station, Tex., 1989.

Shackleton, N.J., Carbon-13 in Uvigerina: Tropical rainforest history and the equatorial Pacific carbonate dissolution cycles, in The Fate of Fossil Fuel $\mathrm{CO}_{2}$ in the Oceans, edited by N.R. Anderson and A. Malahoff, pp. 401-427, Plenum, New York, 1977.

Shackleton, N. J., Oceanic carbon isotope constraints on oxygen and carbon dioxide in the Cenozoic Atmosphere, in Carbon Cycle and Atmospheric CO2: Natural Variations Archean to Present, Geophys. Monogr. Ser., vol. 32, edited by E.T. Sundquist and W.S. Broecker, pp. 412-417, AGU, Washington, D.C., 1985.

Shackleton, N.J., Paleogene stable isotope events, Palaeogeogr Palaeoclimatol. Palaeoecol., 57, 91-102, 1986.

Shackleton, N.J., The carbon isotope record of the Cenozoic; history of organic carbon burial and of oxygen in the ocean and atmosphere, edited by J. Brooks et al., Geol. Soc. Spec. Publ., London, 26, 423434, 1987.

Shackleton, N.J., and J.P. Kennett, Paleotemperature history of the Cenozoic and the initiation of Antarctic glaciation, oxygen and carbon isotope analyses in DSDP Sites 277, 279 and 281, Initial Rep. Deep Sea Drill. Proj., 29, 743-755, 1975.

Shackleton, N.J., M.A. Hall, and A. Boersma, Oxygen and carbon isotope data from Leg 74 foraminifers, Initial Rep. Deep Sea Drill. Proj., 74, 599-612, 1984.

Sloan, L.C., and E.J. Barron, A comparison of Eocene climate model results to quantified paleoclimatic interpretations, Palaeogeogr. Palaeoclimatol. Palaeoecol., 93, 183-202, 1992.

Sloan, L.C., and D.K. Rea, Atmospheric carbon dioxide and early Eocene climate: Ageneral circulation modeling sensitivity study. Palaeogeogr. Palaeoclimatol. Palaeoecol., 119 275-292, 1995.

Southam, J.R., and W.H. Peterson, Transient response of the marine carbon cycle, in Natural Variations in Carbon Dioxide and the Carbon Cycle, Geophys. Monogr. Ser., vol. 32, edited by E.T. Sundquist and W.S. Broecker, pp. 89-98, AGU, Washington, D.C., 1985.

Stott, L.D., J.P. Kennett, N.J. Shackleton, and R.M. Corfield, The evolution of Antarctic surface waters during the Paleogene, Inferences 
from the stable isotopic composition of planktonic foraminifera, Proc. Ocean Drill. Program Sci. Results, 113, 849-864, 1990.

Tauxe, L., P. Tucker, N.P. Petersen, and J.L. LaBrecque, Marine and continental chronostratigraphy, paleoclimatology and paleomagnetism of the Cenozoic, Palaeogeogr. Palaeoclimatol. Palaeoecol., $42,65-90,1983$

Thomas, E., Middle Eocene-late Oligocene bathyal benthic foraminifera (Weddell Sea), faunal changes and implications for ocean circulation, in Eocene-Oligocene Climatic and Biotic Evolution, edited by D.A. Prothero and W.A. Berggren, pp. 245-271, Princeton Univ. Press, Princeton, N. J., 1992a.

Thomas, E., Cenozoic deep-sea circulation: Evidence from deep-sea benthic foraminifera, in The Antarctic Paleoenvironment: A Perspective on Global Change, Antarct. Res. Ser., vol. 56, edited by J.P. Kennett and D.A. Warnke, pp. 141-165, AGU, Washington, D.C., $1992 b$.

Thunell, R.C., and B.H. Corliss, Late Eocene-early Oligocene carbonate sedimentation in the deepsea, in Terminal Eocene Events, edited by C. Pomerol and I. Premoli-Silva, pp. 363-380, Elsevier Sci., New York, 1986.

van Andel, T.H., Mesozoic/Cenozoic calcite compensation depth and the global distribution of calcareous sediments, Earth Planet. Sci. Lett., 26, 187-194, 1975.

Vergnaud-Grazzini, C., and $\mathrm{H}$. Oberhansli, Isotopic events at the Eocene/Oligocene, in Terminal Eocene Events, edited by $\mathrm{C}$. Pomerol, and I. Premoli-Silva, pp. 311-329, Elsevier Sci., New York, 1986

Vincent, E., and W. Berger, Carbon dioxide and polar cooling in the Miocene: The Monterey Hypothesis, in Carbon Dioxide and Atmospheric $\mathrm{CO}_{2}$ : Natural Variations Archean to Present, Geophys. Monogr. Ser., vol. 32, edited by E.T. Sundquist and W.S. Broecker, pp. 455-468, AGU, Washington, D.C., 1985.

Wei, W., Paleogene Chronology of Southern Ocean drill holes: An update, in The Antarctic Paleoenvironment: A Perspective on Global Change, Antarct. Res. Ser., vol. 56, edited by J.P. Kennett and D.A. Warnke, pp. 75-96, AGU, Washington, D.C., 1992.

Wise, S.W., J.R. Breza, D.M. Harwood, and W. Wei, Paleogene glacial history of Antarctica, in Controversies in Modern Geology, pp. 133171, Academic, San Diego, Calif., 1991.

Wolfe, J.A., Climatic, Floristic and vegetational changes near the Eocene/Oligocene boundary in North America, in EoceneOligocene Climatic and Biotic Evolution, edited by D.A. Prothero and W.A. Berggren, pp. 421-436, Princeton Univ. Press, Princeton, N.J., 1992.
Woodruff, F., and S.M. Savin, Mid-Miocene isotope stratigraphy in the deep sea: High-resolution correlations, paleoclimatic cycles, and sediment preservation, Paleoceanography, 6, 755-806, 1991.

Wright, J.D., K.G. Miller, and R. Fairbanks, Early and middle Miocene stable isotopes: Implications for deepwater circulation and climate, Paleoceanography, 7, 357-389, 1992.

Wu, G., J. C. Herguera, and W. H. Berger, Differential dissolution: Modification of late Pleistocene oxygen isotope records in the western equatorial Pacific, Paleoceanography, 5, 581-594, 1990.

Zachos, J.C., J. Breza, and S.W. Wise, Early Oligocene ice-sheet expansion on Antarctica, Sedimentological and isotopic evidence from Kerguelen Plateau, Geology, 20, 569-573, 1992a.

Zachos, J.C., W.A. Berggren, M.P. Aubry, and A. Mackensen, Isotope and trace element geochemistry of Eocene and Oligocene foraminifers from Site 748, Kerguelen Plateau, Proc. Ocean Drill. Program Sci. Results, 120, 839-854, $1992 b$.

Zachos, J.C., D.K. Rea, K. Seto, R. Nomura, and N. Niitsuma, Paleogene and early Neogene deep water paleoceanography of the Indian Ocean as determined from benthic foraminifer stable carbon and oxygen isotope records, in Synthesis of Results From the Scientific Drilling in the Indian Ocean, Geophys. Monogr. Ser., vol. 70, edited by R. Duncan et al., pp. 351-385, AGU, Washington, D.C., $1992 \mathrm{c}$.

Zachos, J.C., K.C. Lohmann, J.C.G. Walker, and S.W. Wise, Abrupt climate change and transient climates in the Paleogene: A marine perspective, J. Geol., 101, 193-215, 1993.

Zahn, R. and L. Diester-Haass, Orbital forcing of Eocene-Oligocene climate: High resolution records of benthic isotopes from ODP Site 689, Maud Rise, paper presented at the 5th International Conference on Paleoceanography, Halifax, Canada, 1995.

Zahn, R., and A.C. Mix, Benthic foraminiferal $\delta^{18} \mathrm{O}$ in the ocean's temperature-salinity-density field: Constraints on Ice Age thermohaline circulation, Paleoceanography, 6, 1-20, 1991.

T.M. Quinn, Department of Geological Sciences, University of South Florida, Tampa Bay, FL 33620.

K.A. Salamy, Marine Sciences Board, University of California, Santa Cruz, CA 95064 (e-mail: salamy @earthsci.ucsc.edu).

J.C. Zachos, Earth Sciences Deparment, University of California,

Santa Cruz, CA 95064 (e-mail: jzachos@earthsci.ucsc.edu).

(Received September 6, 1995; revised February 16, 1996;

accepted February 21, 1996.) 